\title{
41. CARBONATE AND ORGANIC CARBON CYCLES IN APTIAN-ALBIAN BLACK SHALES AT DEEP SEA DRILLING PROJECT SITE 511, FALKLAND PLATEAU ${ }^{1}$
}

\author{
Mary E. Parker, Department of Geology, Florida State University, Tallahassee, Florida \\ Michael A. Arthur, Department of Geology, University of South Carolina, Columbia, South Carolina \\ Sherwood W. Wise, Jr., Department of Geology, Florida State University, Tallahassee, Florida \\ and \\ Chiye R. Wenkam, U.S. Geological Survey, Denver, Colorado
}

\begin{abstract}
Thin but discrete pelagic limestone beds intercalated among the black mudstones near the top of the extensive Mesozoic black shale sequence of the Falkland Plateau are reminiscent of similar occurrences in the central and North Atlantic and may be cyclic in nature. They have been studied via carbonate, organic carbon, stable isotope, nannofloral, and ultrastructural analysis in an attempt to determine their mode of origin. Nannofossil diversity and preservation suggest that selective dissolution or diagenesis did not produce the interbedded coccolith-rich and coccolith-poor layers, nor did blooms of opportunistic species play a role. Stable isotope measurements of carbonate do not adequately constrain the origin of the cyclicity; however, the $\delta^{13} \mathrm{C}$ data suggest that the more nannofossil-rich intervals may be due to higher nutrient supply and overturn of deeper waters at the site rather than influxes of well-oxygenated waters into an otherwise anoxic environment. Such an explanation is in accord with the nannofloral evidence.
\end{abstract}

\section{INTRODUCTION}

A primary objective of Deep Sea Drilling Project Site 511 on the eastern Falkland Plateau $\left(51^{\circ} 00.28^{\prime} \mathrm{S}, 46^{\circ}\right.$ $58.30^{\prime} \mathrm{W}$; Fig. 1) was to core continuously the upper portion of the long Jurassic to lower Albian black shale sequence (Fig. 2) which had previously been spot-cored at DSDP Leg 36 Sites 327 and 330 (Barker, Dalziel, et al., 1977). The successful recovery of cores through this interval at Site 511 has confirmed the existence of a hiatus representing approximately $20 \mathrm{~m}$.y. between the Upper Jurassic and Lower Cretaceous sediments (Site 511 summary, this volume).

Although both the Upper Jurassic and Lower Cretaceous rocks consist of black mudstones, a major difference in the two sequences is the existence of thin but discrete pelagic limestone beds which stand out conspicuously among the thicker black mudstones toward the top of the Lower Cretaceous. These limestones are composed of calcareous nannofossils and, along with the black mudstones, may represent some form of cyclic deposition. In this respect, they are reminiscent of sequences of similar age (Aptian-Albian) reported from DSDP sites in the central Atlantic and North Atlantic ocean basins (e.g., Dean et al., 1978; Arthur, 1979). Studies of those sequences have suggested that the cycles could be periodic in nature and may represent climatic oscillations which influence oceanic circulation, productivity, and terrestrial influx to the oceans (e.g., McCave, 1979; Dean et al., 1978; Arthur, 1979).

There are two important differences, however, between the pelagic sequences on the Falkland Plateau and those developed at more northerly DSDP sites. First,

\footnotetext{
${ }^{1}$ Ludwig, W. J., Krasheninnikov, v. A., et al., Init. Repts. DSDP, 71: Washington (U.S. Govt. Printing Office).
}

the Falkland sequences were deposited at shallow, shelfbreak water depths probably no greater than $\mathbf{4 0 0}$ meters (Sliter, 1977; Basov and Krasheninnikov, this volume), whereas Cretaceous black shales at all other DSDP sites were deposited at bathyal or abyssal depths. Second, black mudstones are the predominant lithology among the cycles on the Falkland Plateau, whereas the carbonate beds dominate the cycles in the pre-mid-Aptian sequences of the other Atlantic sites, giving way to multicolored claystones above.

There are two possible origins of the carbonate cycles in the Falkland Plateau black shale sequence. They could represent periodic incursions of normal open-ocean floras during brief periods of ventilation of surface waters in the otherwise anoxic sedimentary basin. Alternatively, they could represent episodes of upwelling and overturn of the water column in the basin which would enrich otherwise nutrient-poor surface waters. Such periodic overturn under restricted environmental conditions might allow a few opportunistic species rather than a flora of normal diversity to flourish. A further overprint on the carbonate cycles could have resulted from fluctuations in intensity of dissolution. An example of the nutrient-dependent situation may be represented by a thick chalk lamina (about $2 \mathrm{~cm}$ thick) described from the Aptian black mudstones of DSDP Core 330A-3 (Wise and Wind, 1977; see also frontispiece of Barker, Dalziel, et al., 1977). This lamina was composed primarily of fragments of the opportunistic species Braarudosphaera and Micrantholithus.

In order to determine just what the carbonate cycles in the Leg 71 sequence represent, we analyzed selected cycles by two independent methods. One approach was a floral analysis to determine the floral diversity and state of preservation of the calcareous nannofossils. The diversity would show whether we were dealing with op- 


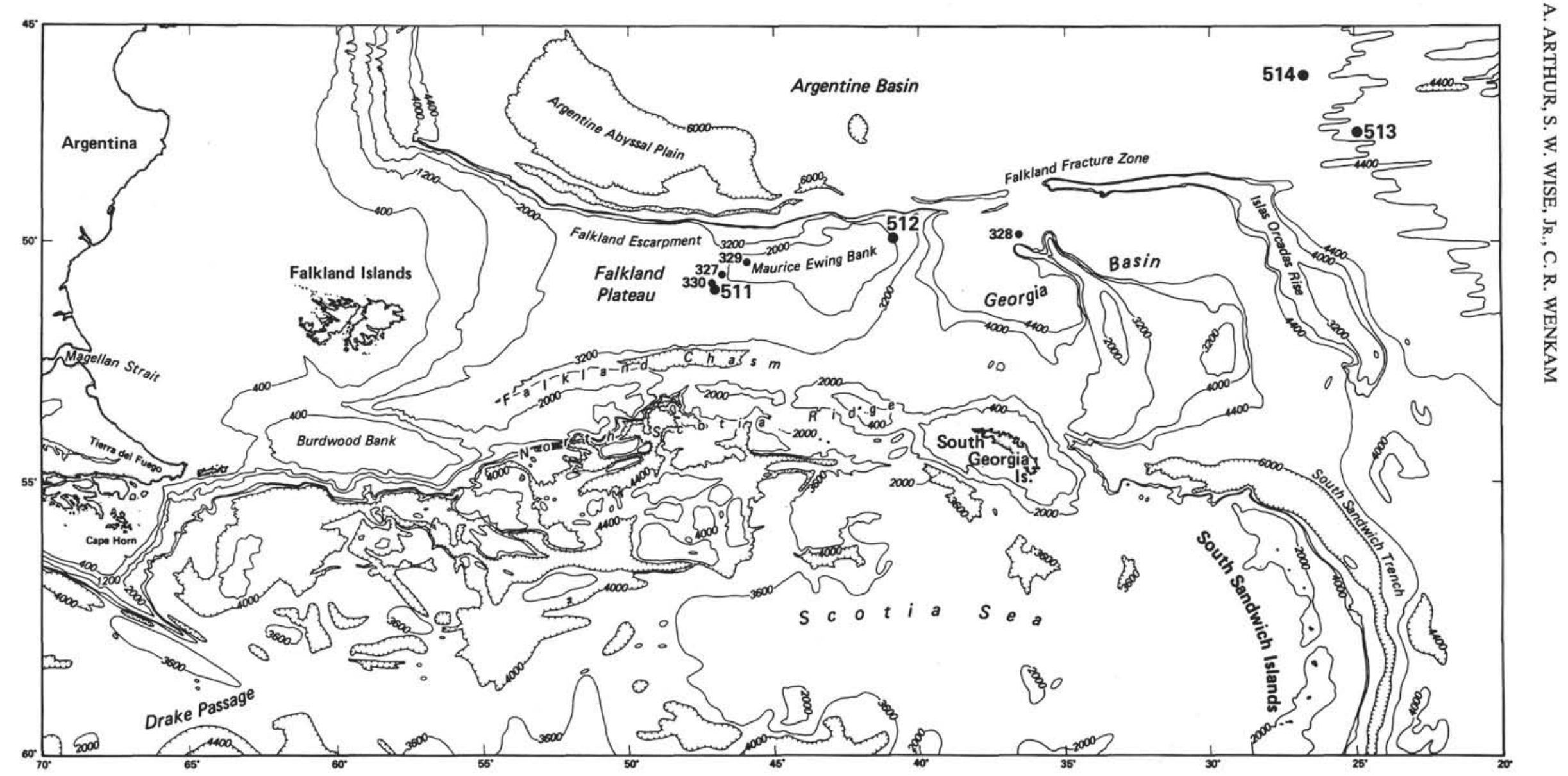

Figure 1. Location of DSDP Site 511, Falkland Plateau. 


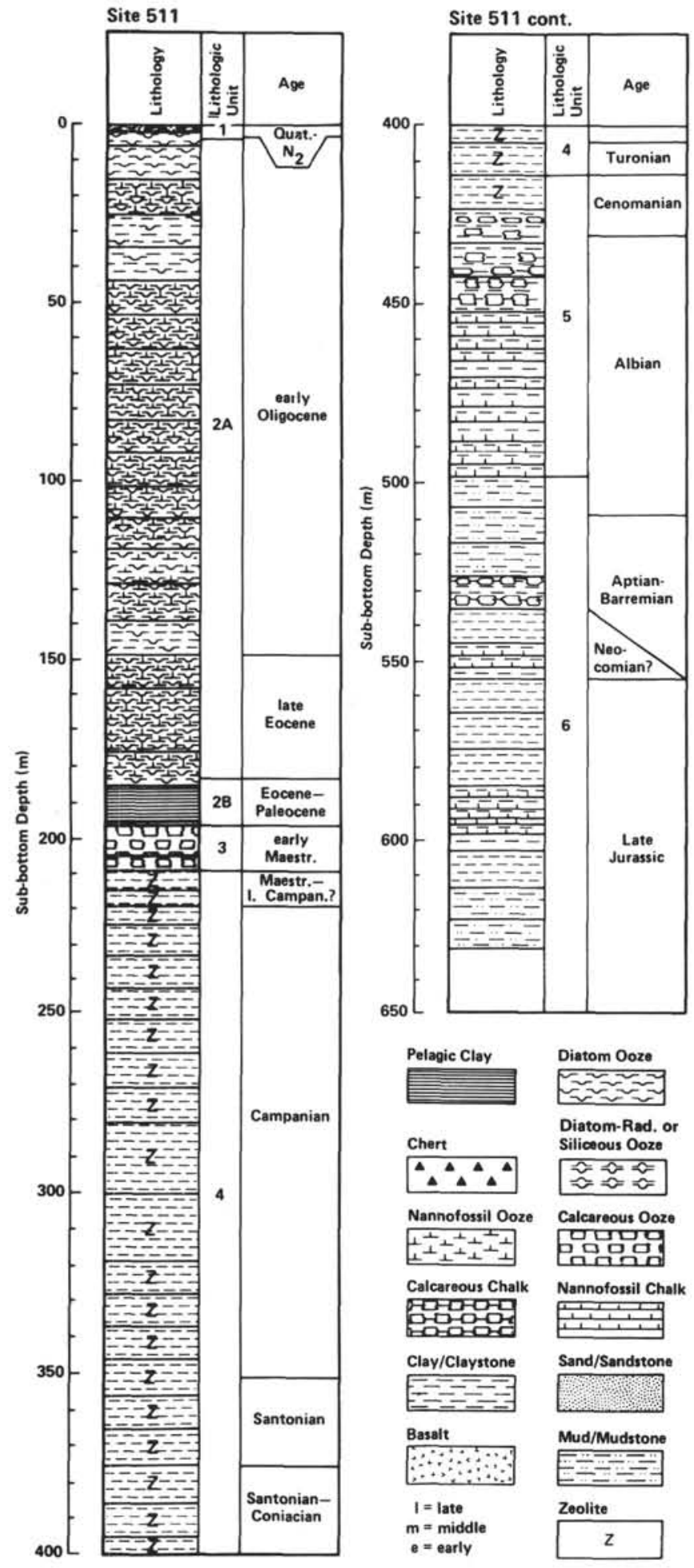

Figure 2. Columnar section of Site 511.

portunistic or normal assemblages. Some assemblages strongly dominated by opportunistic species have been noted in the Falkland Plateau black shales by both Wise and Wind (1977) and by Noël and Manivit (1978). The state of preservation would indicate whether the assemblages were representative of living populations or whether their species compositions had been altered appreciably by post-depositional processes.
The other method involved a carbon and oxygen isotope analysis of the carbonate material. The hypothesis was that we might detect temperature or salinity variations in oceanic surface water environments using $\delta^{18} \mathrm{O}$ values of nannofossil carbonate and productivity changes using $\delta^{13} \mathrm{C}$ as a tracer of nutrient supply.

\section{PREVIOUS WORK}

A number of workers have noted the apparent shortterm cyclicity or periodicity in Cretaceous black shale deposition in the Atlantic. So-called black shale facies rarely consist entirely of organic-carbon-rich dark-colored mud, but instead record alternations in supply and/or preservation of organic carbon, with periods of from 20 to $10010^{3}$ y. (e.g., Dean et al., 1978; McCave, 1979; Arthur, 1979). In many cases the cycles, which are manifested by light and dark mud alternations on a decimeter scale, are fairly regular in appearance, but light and dark cycles also occur in black shale sequences with no apparent rhythmicity (e.g., Site 530; Dean et al., in press). In seeking the causes of the cycles, it has so far been difficult to distinguish the possible superimposed effects of periodic variations in organic carbon supply from changes in preservation that are due to variations in bottom-water oxygen levels (e.g., Tucholke and Vogt, 1979). Undoubtedly each plays an important role, but the degree of influence may vary from basin to basin. Variations in organic carbon supply and in bottom-water oxygen levels are probably coupled (e.g., Dean et al., 1978), yet high productivity over a given site is not necessary to induce bottom-water anoxia (as in the Holocene Black Sea setting), nor does it necessarily result in bottom-water anoxia. A further complication is that variations in the input of organic matter to deeper marine sediments may not be related to changes in surface productivity over the site, but may be due to periodic input by downslope transport and redeposition of sediment from shallower water sources rich in terrestriallyderived organic carbon (e.g., de Graciansky and Chenet, 1979; de Graciansky et al., 1979; Habib, 1979) or in marine organic carbon as from within a midwater oxygen-minimum zone (Dean et al., in press; Arthur et al., in press; also see Thiede and van Andel, 1977). In the following sections, we attempt to constrain the variables and argue that the light- and dark-colored carbonate and organic carbon cycles are due to changes in surface water productivity superimposed on changes in oxygenation of deeper waters.

\section{RESULTS}

\section{Organic Carbon Contents and Preservation at DSDP Site 511}

Von der Dick et al. (this volume) have presented results of a preliminary study of organic matter in the black shale facies (Unit 6) of DSDP Site 511. Enhanced preservation of marine autochthonous organic matter occurred in strata of Neocomian through Aptian age in Cores 59 and below. An average organic carbon value for Unit 6 is about $3.5 \mathrm{wt} . \%$ with individual values as high as 8.5 wt. \%; however, in Cores 57 and 58, which 
we studied in detail, the mean organic carbon content is about 0.3 wt. $\%$ with only 5 out of 36 values over 1.0 wt.\%. The atomic $\mathrm{H} / \mathrm{C}$ and $\mathrm{O} / \mathrm{C}$ ratios for kerogen in Cores 57 and 58 shown by von der Dick (this volume) are characteristic of highly oxidized residual marine organic matter and/or terrestrial higher plant detritus. This is in contrast to the apparent good preservation of marine autochthonous organic carbon which is found in strata of Cores 59 and below and which is characterized by high atomic $\mathrm{H} / \mathrm{C}$ and low $\mathrm{O} / \mathrm{C}$ ratios.

Organic carbon contents and other geochemical indicators suggest that there was a significant change in paleoenvironment on the Falkland Plateau during the early Albian. The conditions which resulted in higher organic carbon contents during much of the Early Cretaceous at Site 511 were either high productivity, preservation under a marginally oxic to anoxic intermediate water mass, or some combination of the two. Evidence of high productivity is generally lacking. Although organic carbon contents are moderately high, organic carbon accumulation rates are relatively low (average 5-30 $\times 10^{-2} \mathrm{~g} / \mathrm{cm}^{2}$ per $10^{3} \mathrm{y}$.) when compared with those typical of modern high-productivity regions (range of 70$270 \times 10^{-2} \mathrm{~g} / \mathrm{cm}^{2}$ per $10^{3} \mathrm{y}$; data from Muller and Suess, 1979; Glenn and Arthur, 1982). Also, biogenic silica in the form of radiolarian tests is present, but not in great abundance; many of the tests have been dissolved (Plate 2, Fig. 9; Plate 5, Fig. 6; Plate 6, Figs. 2-3). Most modern high-productivity settings are characterized by high biogenic silica accumulation rates and commonly consist, at least in part, of biosiliceous sediment (e.g., Heath, 1974; Diester-Haass and Schrader, 1979; DeMaster, 1981). Therefore, we conclude that the relatively high organic carbon contents in Unit 6 black shales at Site 511 did not result from abnormally high productivity, but that they may have originated from a combination of enhanced preservation under poorly oxygenated conditions at a relatively shallow water depth (e.g., about $400 \mathrm{~m}$ ) with fluctuating surface productivity. The shallow depth of the seafloor at Site 511 aided in preserving a greater proportion of the organic matter produced in surface waters, because the dominant fecal pellet transport (see "Nannofossil Analysis" later) of organic matter provides for a rapid descent and low residence time in oxygenated water masses (e.g., Suess, 1980). The low oxygen contents of intermediate to bottom waters in the Argentine Basin would have limited benthic activity and decreased the residence time of organic matter in the zone of oxidation. High sedimentation rates (e.g., Müller and Suess, 1979) were probably not a factor in organic preservation, because average rates are about 0.5 to $1 \mathrm{~cm} / 10^{3} \mathrm{y}$. in the Early Cretaceous.

The major change in organic carbon preservational patterns from Cores 59 to 58 and above occurred in the early Albian. This pattern is similar to that of other sites drilled in the Cape Basin (e.g., Site 361; Natland, 1978; Arthur and Natland, 1979) and is interpreted to reflect an amelioration of the anoxic conditions that existed in the narrow, restricted, early-opening South Atlantic at that time.
However, at DSDP sites in the Angola Basin, evidence of at least periodic anoxia occurs in Albian through Coniacian strata (Arthur and Natland, 1979; Dean et al., in press). At Site 511, the Albian strata exhibit cyclic fluctuations in organic carbon and carbonate content which might indicate periodic changes in productivity or bottom-water oxygenation, even though the overall preservation of organic matter in this interval is poor (von der Dick, et al., this volume).

\section{Lithology of Cretaceous Carbonate Cycles at Site 511}

Cores 56 through 58 of lower to middle Albian and Aptian age consist of black shale or black mudstone which is marked by common, thin ( $<10 \mathrm{~cm}$ thick) intercalations of greenish gray to gray mud to chalky mud, as shown in Figure 3 (see also Frontispiece of this volume for color photographs of these cores). The lightercolored intervals contain relatively less organic carbon (generally $<0.2 \%$ ) and more carbonate (Fig. 4) than the black layers, although organic carbon contents are low for this upper part of Unit 6 (black shale) and carbonate contents, although low (typically $<15 \%$ ), are higher than those in the lower part of Unit 6.

The lighter intervals are homogeneous to mottled, and burrows of Zoophycus and Chondrites are common, in addition, fragments of benthic mollusks ( $\mathrm{Au}$ cellina and inoceramids) are common, although these also occur in darker but still bioturbated intervals. The dark muds range from homogeneous to burrowed to finely laminated. In the cores we examined (Cores 5658 ), it appears that the supply of oxygen to the bottom may have fluctuated somewhat, restricting the activity of benthic metazoan infaunal organisms at times, but generally allowing some bioturbation throughout the sequence. Lighter-colored intervals, however, appear to be more highly burrowed. These intervals are also more rich in calcareous nannofossils. Color and carbonate content appear to grade from base to top in each lightcolored layer (Fig. 3; Core 57) suggesting some gradational environmental change. The periodicity of the dark-light cycles is at least 100,000 y., but the cycles do not appear to be as regular as those at many other Atlantic DSDP sites. The lighter-colored layers appear not to have been redeposited, but some dark-colored layers exhibit sharp basal contacts and other features which could indicate some redeposition, even though the seafloor at the site was probably relatively shallow during the Early Cretaceous.

\section{Organic Carbon, Carbonate, and Stable Isotope Analyses}

Samples of interbedded black and gray mud to chalky mud were analyzed in the U.S.C. laboratory for organic carbon and carbonate contents (Table 1; plotted for several of the cycles in Fig. 3; see also Fig. 4) using a LECO carbon analyzer and standard methods. Stable isotope analyses of the carbonate fraction of each sample were also obtained. $\mathrm{CO}_{2}$ gas was prepared using standard methods (e.g., Craig, 1957, 1965), and analyses for stable carbon and oxygen isotopic compositions were provided by Global Geochemistry Corporation, 
Core Sections, Core 511-57, Albian

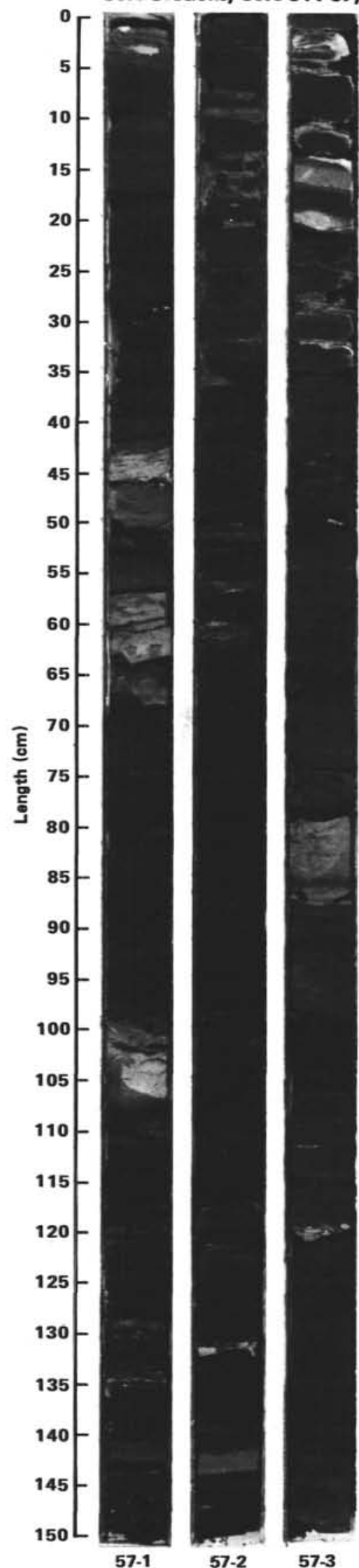

Core Sections, Core 511-58, Aptian
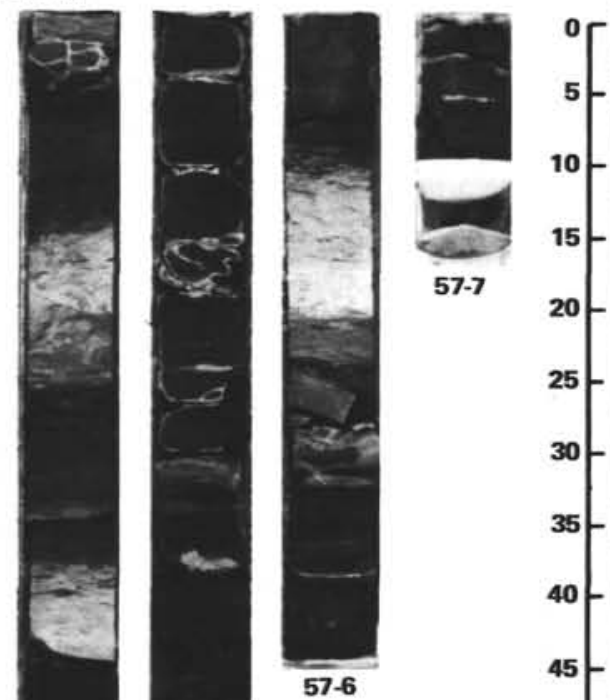

57-7

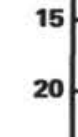

25

25

30

40

4

45

55

60

65

70

75
80

85

90

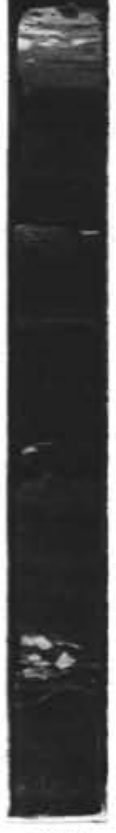

57-5

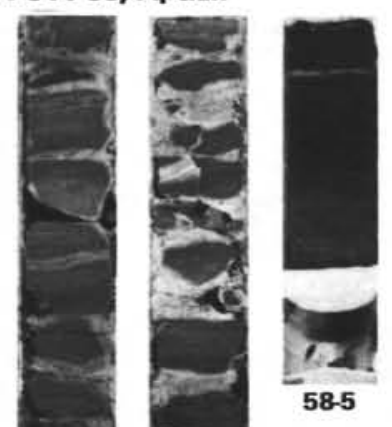

axing

$58-5$

Figure 3. Core sections, showing pelagic limestone intervals (light-colored layers) contrasted with black Albian and Aptian mudstones. 

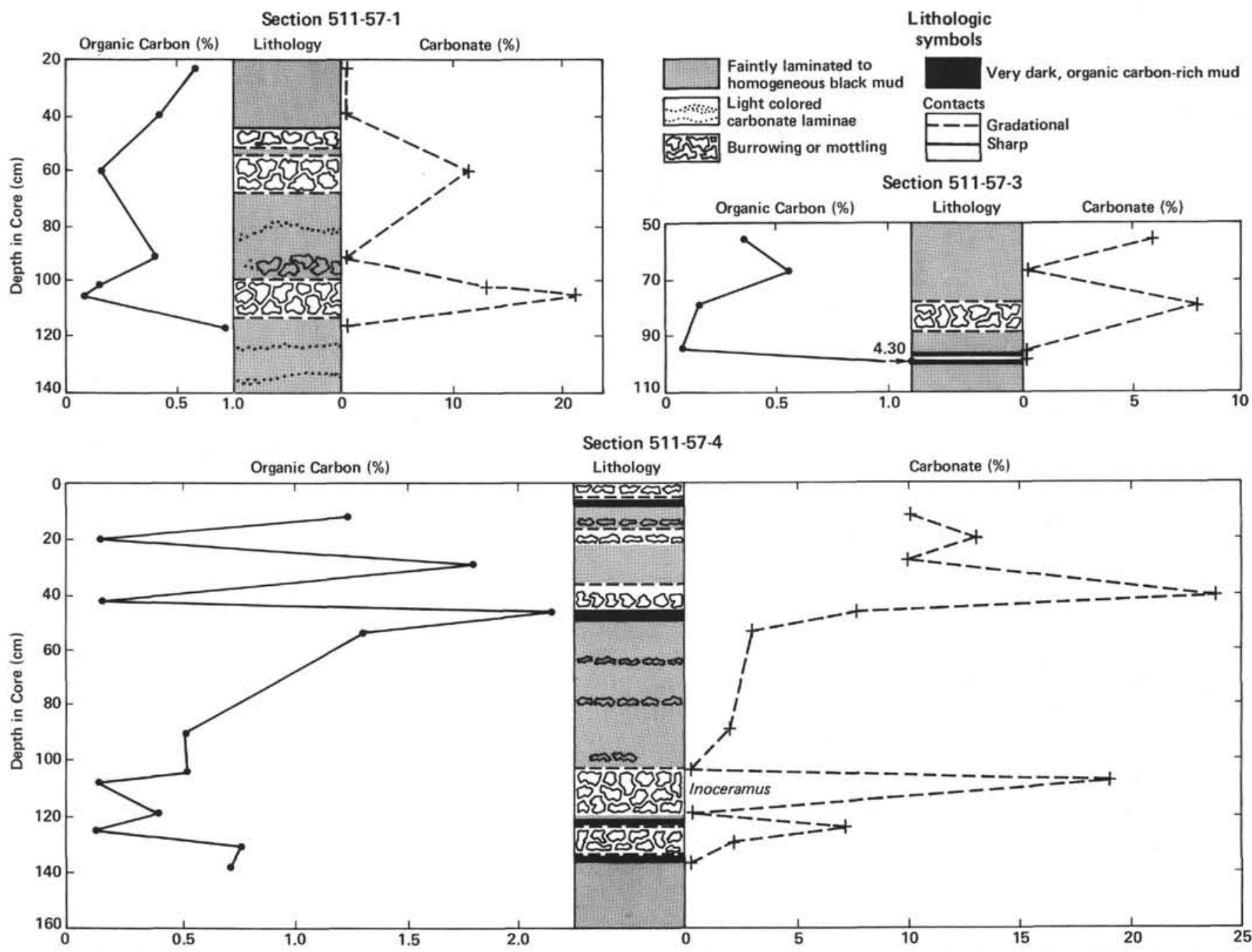

Figure 4. Variations in calcium carbonate and organic carbon contents through limestone/mudstone cycles in Sections 511-57-1, 511-57-3, and $511-57-4$

contracted by the U.S. Geological Survey because gas samples were generally too small to analyze on mass spectrometers available at the U.S.G.S., Denver. Stable isotopic values (Table 1) are reported by standard delta $(\delta)$ notation relative to the PDB standard:

$$
\delta^{18} \mathrm{O} \%_{\mathrm{PDB}}=\left[\frac{18 / 16 \mathrm{O} \text { samp }}{18 / 16 \mathrm{O} \text { std }}-1\right] \times 1000 .
$$

No analyses were performed on samples with less than 1 wt. $\% \mathrm{CaCO}_{3}$ because available samples were too small, and it is not certain that values obtained would be interpretable.

The results of the stable isotopic analyses for each set of lithologic cycles are plotted in Figure 5. Organic carbon and carbonate contents are negatively (but not linearly) correlated in general (Fig. 6); samples with organic carbon contents greater than $0.5 \%$ nearly always have carbonate contents below $5 \%$, and all samples having carbonate contents greater than $10 \%$ have organic carbon values of less than $0.25 \%$. The lack of a linear negative correlation between organic carbon and carbonate suggests that the two do not covary because of mutual dilution. However, it does appear that higher organic carbon values are associated with clay-rich intervals. The deposition of relatively nannofossil rich, light-colored sediment is not accompanied by enhanced preservation of organic matter. This is further evidenced by the abundant signs of burrowing of light-colored, more carbonate rich strata.

A plot of $\delta^{18} \mathrm{O}$ versus $\delta^{13} \mathrm{C}$ (Fig. 7) exhibits no systematic relationship between the two. There is a broad spread of $\delta^{13} \mathrm{C}$ values ( 0 to $4.22 \%$ with a clustering toward relatively heavy or more positive values $(+2$ to +4 $\%$ ). These values are typical for pelagic carbonates on a global scale during the late Aptian-early Albian (Scholle and Arthur, 1980). $\delta^{18} \mathrm{O}$ values have a narrow range $(-1.5 \%$ to $-4 \%$ ) with most values clustering near $-2 \%$. The latter $\delta^{18} \mathrm{O}$ value would indicate an equilibrium isotopic paleotemperature of about $20^{\circ} \mathrm{C}$ for an icefree world and is not out of line for the high paleolatitude of the Falkland Plateau during the Early Cretaceous. Clearly, however, $\delta^{18} \mathrm{O}$ values less than -1 or greater than $-3 \%$ indicate either analytical problems (marked with triangles in Fig. 7; both samples contained less than $1 \% \mathrm{CaCO}_{3}$ ) or possible diagenetic recrystalli- 
Table 1. Stable isotope (carbonates), organic carbon, and carbonate data for Site 511, Cores 57-59.

\begin{tabular}{|c|c|c|c|c|}
\hline $\begin{array}{l}\text { Core/Section } \\
\text { (interval in } \mathrm{cm} \text { ) }\end{array}$ & $\delta^{13} \mathrm{C}$ & $\delta^{18} \mathrm{O}$ & $\mathrm{C}_{\text {org }}(\%)$ & $\mathrm{CaCO}_{3}(\%)$ \\
\hline $57-1,24-26$ & - & - & 0.57 & $<1$ \\
\hline $57-1,39-41$ & - & - & 0.42 & $<1$ \\
\hline $57-1,59-61$ & +3.90 & -2.10 & 0.15 & 12 \\
\hline $57-1,91-93$ & - & - & 0.42 & $<1$ \\
\hline $57-1,99-101$ & +4.22 & -1.19 & 0.16 & 13 \\
\hline $57-1,105-107$ & +3.74 & -2.40 & 0.09 & 21 \\
\hline $57-1,114-116$ & - & - & 0.74 & $<1$ \\
\hline $57-3,55-57$ & +2.57 & -1.96 & 0.35 & 6 \\
\hline $57-3,67-68$ & - & - & 0.55 & 1 \\
\hline $57-3,79-81$ & +3.38 & -1.92 & 0.14 & 8 \\
\hline $57-3,94-95$ & - & - & 0.08 & $<1$ \\
\hline $57-3,101-103$ & - & - & 4.30 & $<1$ \\
\hline $57-4,12-14$ & +3.25 & -2.42 & 1.23 & 10 \\
\hline $57-4,19-21$ & +2.21 & -2.34 & 0.11 & 13 \\
\hline $57-4,29-31$ & +3.50 & -2.06 & 1.78 & 10 \\
\hline $57-4,42-44$ & +0.91 & -1.76 & 0.13 & 24 \\
\hline $57-4,46-48$ & +3.73 & -4.02 & 2.14 & 8 \\
\hline $57-4,54-56$ & -0.23 & -0.69 & 1.30 & 3 \\
\hline $57-4,90-92$ & +1.77 & -1.41 & 0.50 & 2 \\
\hline $57-4,104-106$ & -0.12 & -2.12 & 0.51 & $<1$ \\
\hline $57-4,108-110$ & +2.08 & -2.96 & 0.10 & 19 \\
\hline $57-4,119-121$ & - & - & 0.37 & $<1$ \\
\hline $57-4,125-126$ & +3.70 & -2.18 & 0.08 & 7 \\
\hline $57-4,131-133$ & +1.53 & -2.47 & 0.75 & 2 \\
\hline $57-4,137-139$ & - & - & 0.71 & $<1$ \\
\hline $57-5,74-76$ & +2.57 & -3.30 & 0.16 & 2 \\
\hline $57-5,83-85$ & +1.87 & -1.83 & 0.44 & $<1$ \\
\hline $57-5,101-103$ & +3.55 & -2.14 & 0.95 & 8 \\
\hline $57-5,106-108$ & +2.67 & -0.42 & 0.95 & 6 \\
\hline $57-6,4-5$ & +3.32 & -2.37 & 0.62 & 4 \\
\hline $57-6,15-17$ & -1.89 & -3.42 & 0.07 & 45 \\
\hline $57-6,41-43$ & +3.15 & -3.01 & 0.51 & 3 \\
\hline $58-2,77-79$ & +2.87 & -1.66 & 0.39 & 3 \\
\hline $58-2,99-101$ & +1.97 & -3.90 & 0.17 & 17 \\
\hline $58-2,108-110$ & -2.24 & -3.48 & 0.34 & $<1$ \\
\hline $59-1,83-85$ & - & - & 0.54 & $<1$ \\
\hline
\end{tabular}

Note: Dash means that there was not enough to be measured.

zation and equilibration at higher temperatures. Carbon isotope values in pelagic carbonates are generally less difficult to alter during diagenesis because the reservoir of rock carbon is typically larger than that of water carbon. In organic-carbon-rich sequences, however, particularly when the total carbonate contents are low $(<30 \%)$, organic matter degradation can contribute isotopically light $\mathrm{CO}_{2}$ and cements may become depleted (e.g., Hudson, 1977). On the basis of our SEM studies, which show no extensive recrystallization of carbonate, and the reasonable $\delta^{18} \mathrm{O}$ and $\delta^{13} \mathrm{C}$ values, we feel that the stable isotopic data probably reflect some original, primary signal.

Figure 8 shows the relationship between $\delta^{13} \mathrm{C}$ and carbonate content. In a very general way, there appears to be a trend toward lighter $\delta^{13} \mathrm{C}$ values with decreasing carbonate contents below $10 \%$. This trend reverses above $10 \% \mathrm{CaCO}_{3}$. Neither trend is statistically significant. The first trend could be interpreted as a lightening of $\delta^{13} \mathrm{C}$ because of increasing diagenetic addition of light carbon from organic carbon degradation with progressively lower initial carbonate contents. There is no systematic relationship between the $\delta^{13} \mathrm{C}$ of carbonate and organic carbon content of samples (Fig. 9).
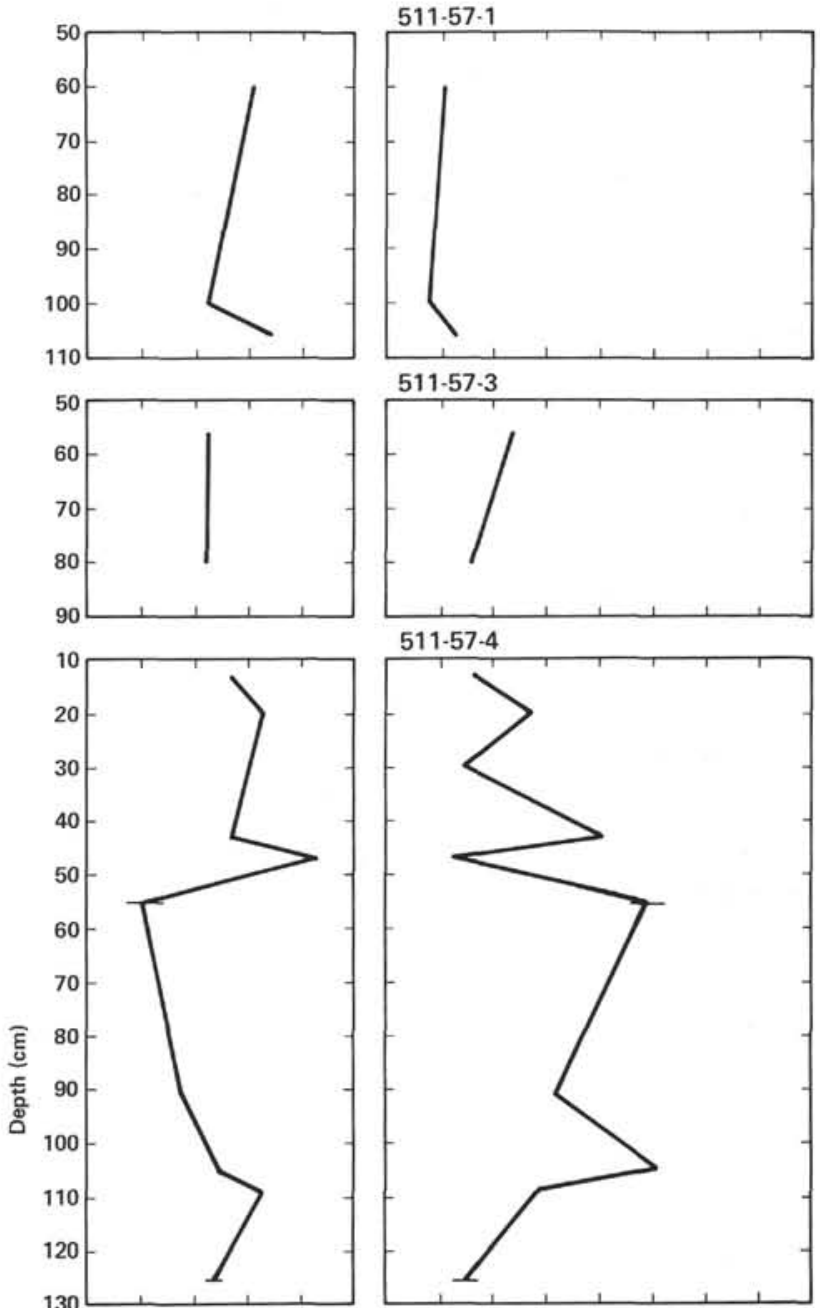

$511-57.4$
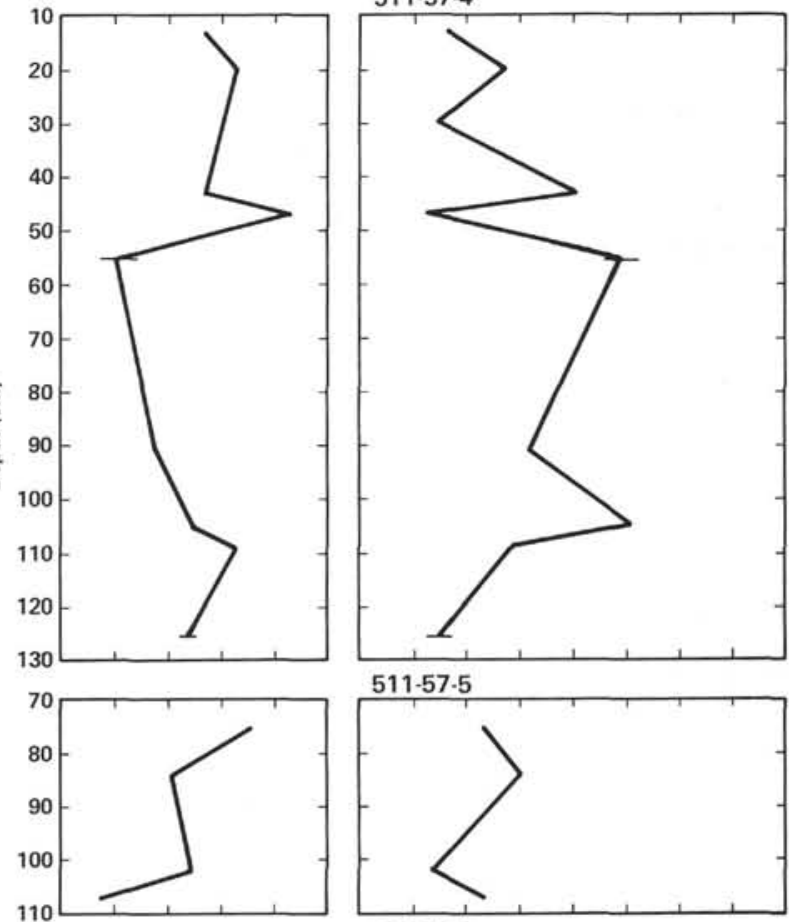

$511-57.5$
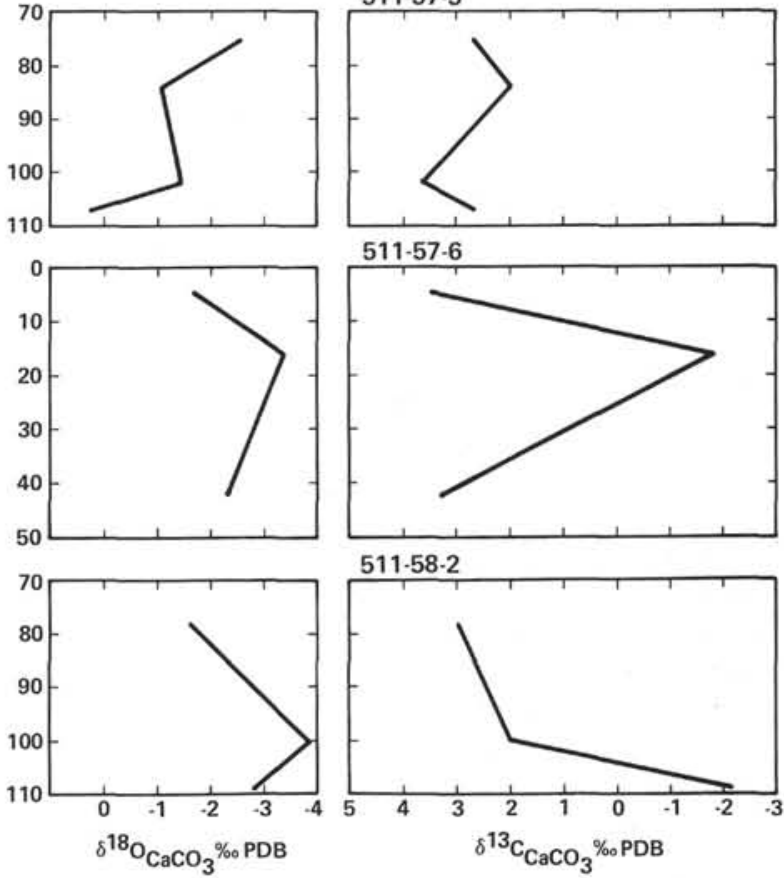

511.58-2

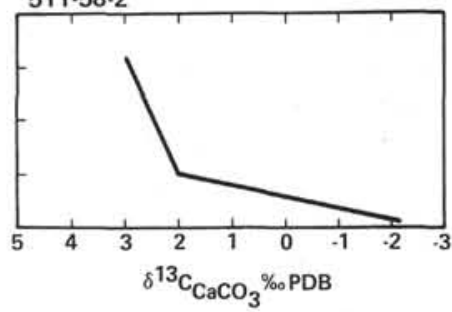

Figure 5. Variations in carbon and oxygen stable isotope values through limestone/mudstone cycles in Sections 511-57-1, 511-57-3, $511-57-4,511-57-5,511-57-6$, and 511-58-2. 


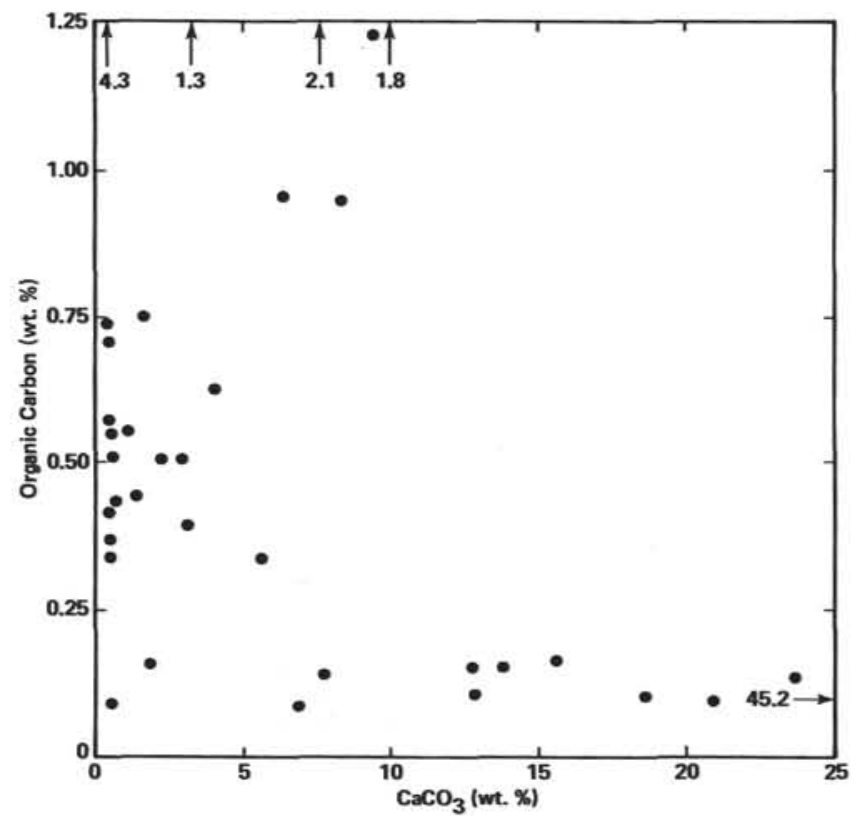

Figure 6. Calcium carbonate versus organic carbon for all core samples; correlation negative but not linear.

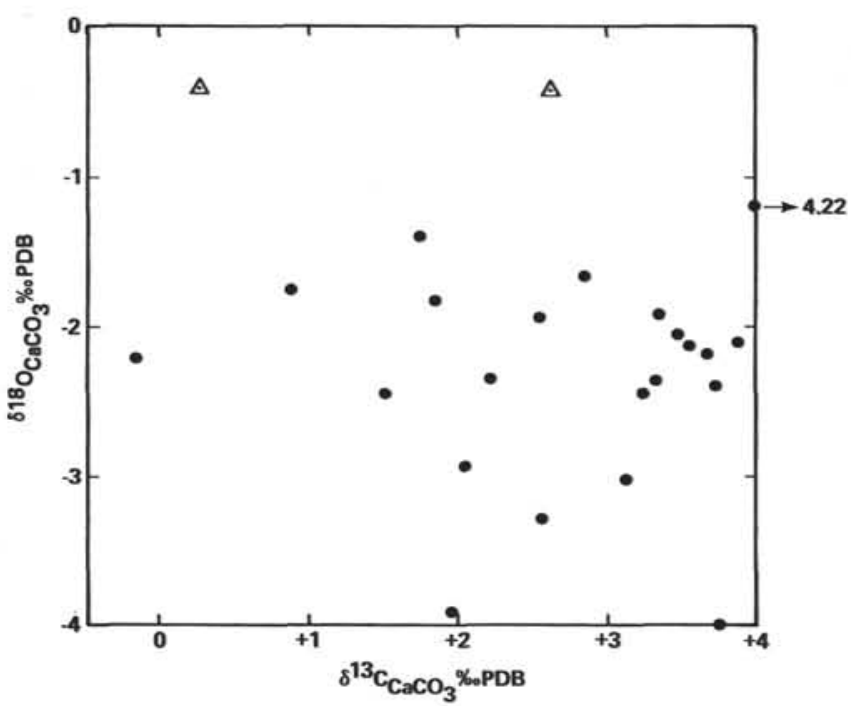

Figure 7. Oxygen versus carbon stable isotope values for all core samples; no apparent systematic relationship between the two. (Triangles mark spurious values.)

The stable isotope data, then, do not provide for a clear interpretation of the origin of intercalation of calcareous nannofossil-rich and nannofossil-poor beds. The samples with highest carbonate contents (above 10\%), however, have progressively lower $\delta^{13} \mathrm{C}$ which, if original, might indicate that an increase in the nutrient supply and isotopically light total $\mathrm{CO}_{2}$ of surface waters and higher carbonate production provide the origin of the relatively carbonate-rich beds.

\section{Nannofloral Analysis}

Two carbonate cycles were sampled for the nannofloral analysis. The first cycle is at the base of the Albian section and is readily distinguished in Section 511-

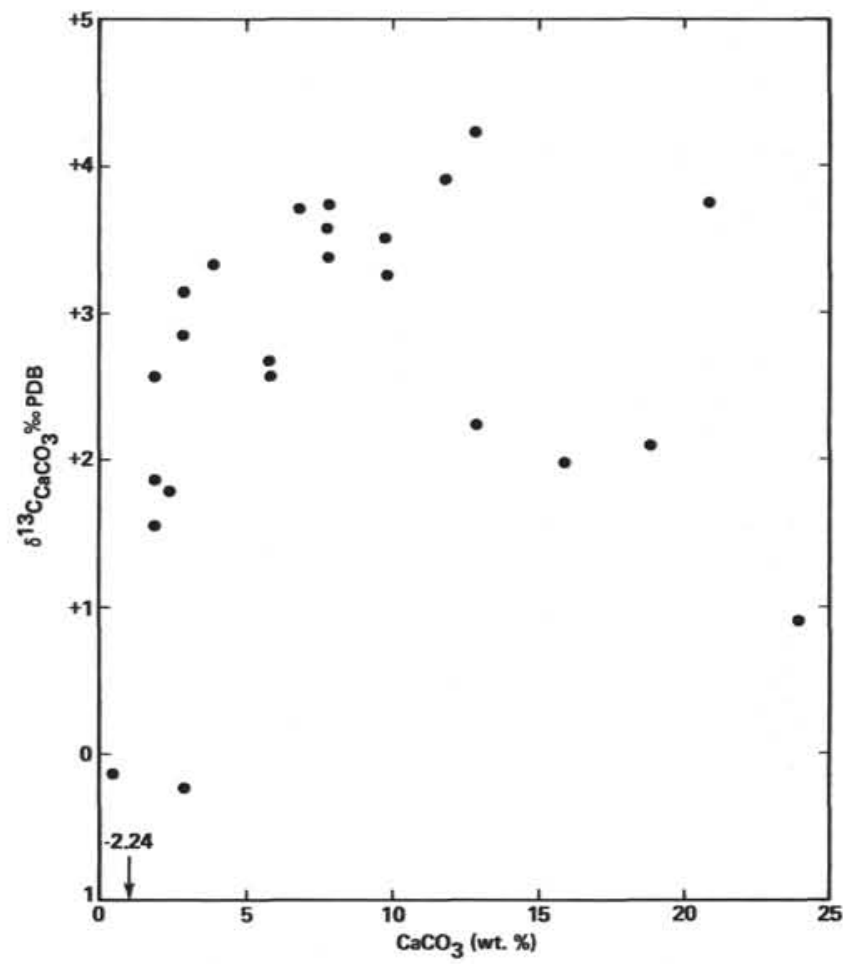

Figure 8. Calcium carbonate content versus $\delta^{13} \mathrm{C}$ for all core samples.

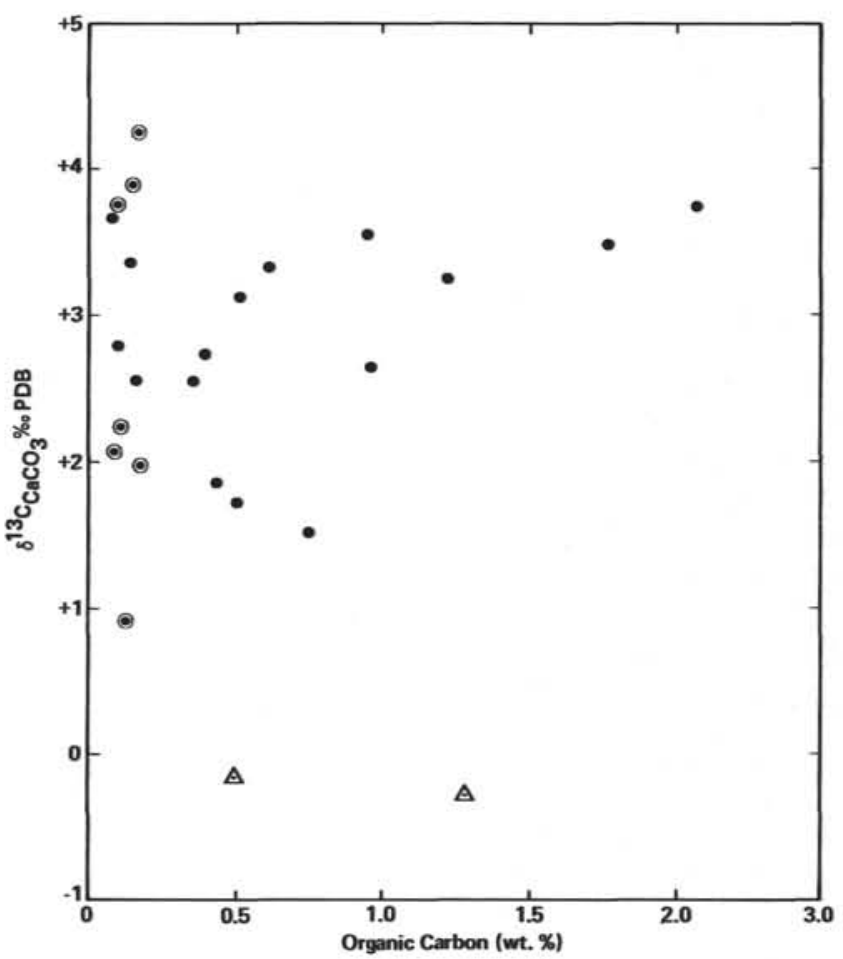

Figure 9. Organic carbon content versus $\delta^{13} \mathrm{C}$ for all core samples. (Circled values $=$ samples with $>10 \% \mathrm{CaCO}_{3}$; triangles $=$ known diagenetically altered samples.)

57-6 (Fig. 3) where a whitish, heavily burrowed limestone between 10 and $20 \mathrm{~cm}$ is interbedded between finely laminated black mudstones. Samples examined in the SEM were 511-57-6, $4 \mathrm{~cm}$ (black mudstone), 511-57-6, $15 \mathrm{~cm}$ (white limestone), and 511-57-6, $41 \mathrm{~cm}$ (black 
mudstone). The second cycle is in the upper portion of the Aptian section and is the only cycle in Section 51158-2 (Fig. 3). In this cycle samples examined were 51158-2, $77 \mathrm{~cm}$ (black mudstone); 511-58-2, $99 \mathrm{~cm}$ (white mudstone); and 511-58-2, $108 \mathrm{~cm}$ (black mudstone).

During routine light microscope examination of coccoliths in smear slides (Wise, this volume), calcareous nannofossils from the white limestones in these two cycles were reported to be common whereas coccoliths from black mudstones in these cores were reported to be scarce to absent. Preservation in the white limestones was reported to be moderate with some etching and overgrowth.

\section{Albian Cycle, Section 511-57-6}

Scanning electron micrographs of fracture sections of the black mudstone in Sample 511-57-6, $4 \mathrm{~cm}$ are shown on Plates 1 to 3. Plate 1, Figures 1 and 2 are rather characteristic, showing a background of clay particles with coccoliths, mostly Watznaueria, scattered throughout the matrix. There are also some large (at this scale) angular cavities within the rock which may have formed from the dissolution of lath-shaped mineral grains (Plate 1, Fig. 2). There is some tendency for the coccoliths to be clustered (Plate 1, Figs. 3 and 4), although in general they are also dispersed widely throughout the matrix. The diversity of the assemblages as determined from inspection of the electron micrographs is given in the occurrence chart in Figure 10.

Three aspects of the nannofossil assemblage are somewhat surprising. They are more numerous and more diverse than expected from the smear slide examination of black shales from this core. In addition, the coccoliths are generally quite well preserved, as noted in closeup photographs on Plates 2 and 3 . The intact coccoliths show little if any sign of etching, and even the most delicate forms such as the various species of Corollithion (Plate 2, Figs. 6-8) are quite well preserved. The only real damage to the specimens evidently resulted from mechanical tearing when the section was fractured during specimen preparation. This accounts for the torn spine on the specimen of Axopodorhabdus in Plate 2, Figure 4 and the missing elements along the inner cycle of the shield of the Watznaueria (arrow) in Plate 2, Figure 2. The impression of a coccolith in Plate 2, Figure 1 is also attributed to mechanical separation of the coccolith from the matrix when the rock was fractured during specimen preparation.

The only obvious evidence of chemical etching of microfossils is the impression of a radiolarian test (Plate 2, Fig. 5) which has been completely removed by dissolution. This indicates that the mineral grains represented by rectangular molds in Plate 1, Figure 2, were probably siliceous in composition. In contrast, the coccoliths adjacent to those molds are completely unaffected by dissolution, and one must search carefully among the clay matrix to find coccoliths which show any appreciable dissolution (Plate 3, Fig. 2).

In contrast to the black shale above, the preservation of coccoliths in the white limestone of Sample 511-57-6, $15 \mathrm{~cm}$ is rather variable (Plate 3, Figs. 3-4; Plate 4, Figs. 1-3). There seems to have been some dissolution and reprecipitation of calcite which has badly obscured the fine features of the surfaces of the coccoliths. As in the black shale, the coccoliths are apparently diverse and some delicate forms are present (Corollithion, lower left of Plate 4, Fig. 1), but their ultrastructural features have been sufficiently obscured to discourage serious taxonomic study. The coccoliths are quite evenly dispersed throughout the rock and there is no evidence of the clustering noted in the black shale sample. All of these features, the poor preservation and the even dispersion, can probably be attributed in part to the intense bioturbation that this sediment underwent upon deposition.

In contrast to the even dispersal of coccoliths throughout the whitish limestone, coccoliths in the underlying

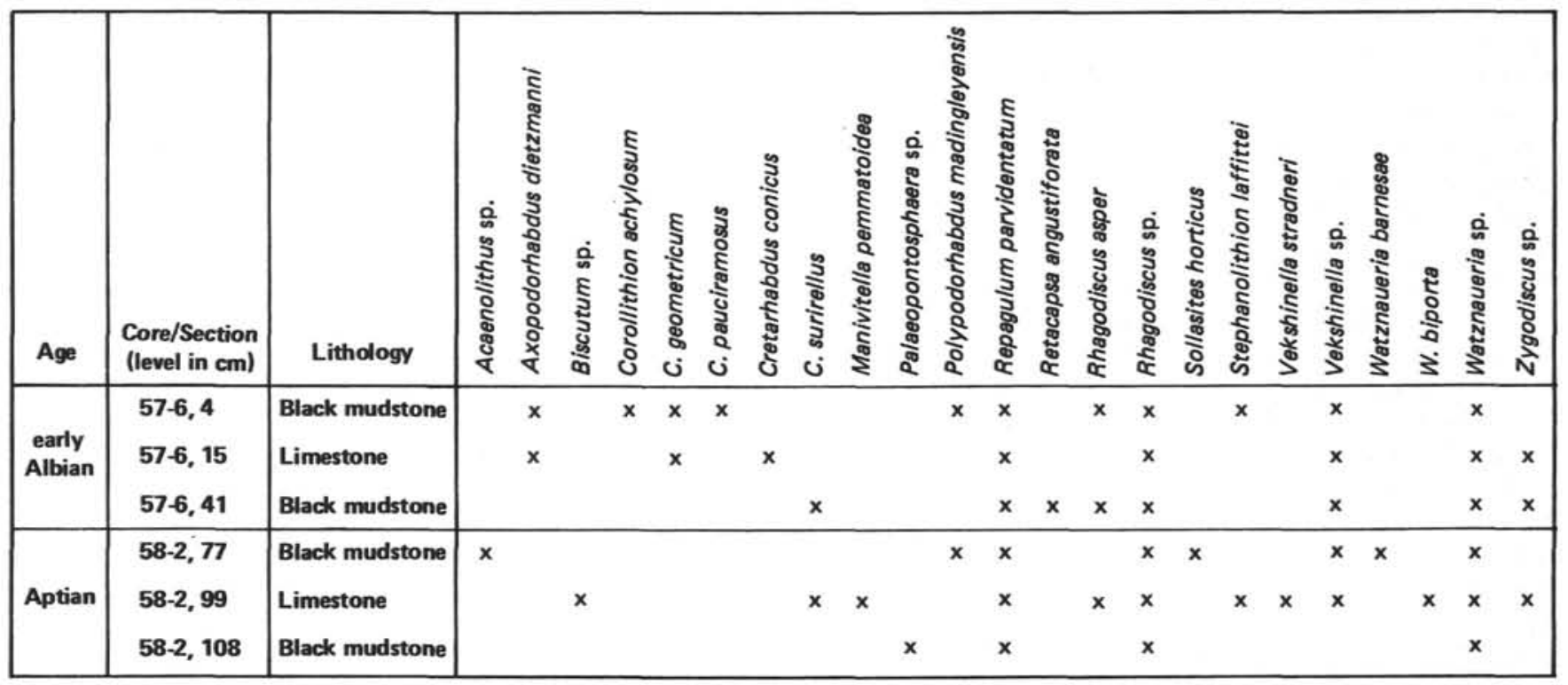

Figure 10. Occurrence of coccoliths in two carbonate cycles, as determined by inspection of electron micrographs, Site 511 . 
black mudstone (Sample 511-57-6, $41 \mathrm{~cm}$ ) occur concentrated in clusters or pods which stand out from the clay matrix of the rock (Plate 4, Fig. 4). Few coccoliths were noted scattered about within the matrix. These pods of isolated coccoliths probably represent fecal pellets produced by grazing zooplankton as described by Hattin (1975), Honjo (1976), and Roth et al. (1975).

The range of preservation of coccoliths within the black mudstone is variable (Plate 5, Figs. 1-6). Some specimens appear to be reasonably intact (Plate 5, Figs. 2 and 5), whereas others show slight to heavy dissolution (Plate 5, Figs. 1 and 4, respectively). Silica dissolution is indicated by the partially dissolved radiolarian test in Plate 5, Figure 6.

\section{Aptian Cycle, Section 511-58-2}

Core 58 is well down the section within the "black shale" sequence. In general, coccoliths (Plate 5, lower half, to Plate 8) are more sparse in both the white and dark lithologies than in Core 57, but diversity remains reasonably high (Fig. 10). Secondly, they tend to occur more in pods or clusters. As mentioned above, we believe these pods represent fecal pellets produced by surface grazers. In the whitish limestone layers, these clusters are more numerous and larger in extent than in the dark layers. In the latter, the pods are so rare that it was sometimes necessary to locate them by use of the elemental energy dispersive X-ray unit attached to the SEM. The procedure was to map the fracture surface for calcium at low magnification. Small isolated areas that showed up positive for calcium (sometimes only a few such areas per specimen) invariably on closer examination turned out to represent a cluster of coccoliths.

The black mudstone Sample 511-58-2, $77 \mathrm{~cm}$ above the white limestone in Section 511-58-2 exhibits wellpreserved and poorly preserved coccoliths, depending upon where they occur. Open cavities within the rock (Plate 6, Fig. 1) contain a fair number of well-preserved coccoliths with some species diversity, as seen in closeup photographs (Plate 6, Fig. 2; Plate 5, Fig. 9). Coccoliths adjacent to cavities left by the dissolution of radiolarian tests (Plate 6, Figs. 3-5) are also well preserved. Except for the radiolarian mold, the fracture surface in Plate 6, Figure 1 cuts through the solid clay matrix of the rock. This matrix is nearly devoid of coccoliths. The few that are found embedded within this matrix are poorly preserved and show clear signs of dissolution (Plate 5, Figs. 7-8).

Coccoliths in the whitish limestone of Sample 511$58-2,99 \mathrm{~cm}$ are grouped in large clusters (Plate 7, Figs. 1-2) separated by areas which are nearly barren of nannofossils. Diversity is high although delicate forms such as Corollithion are absent. Their absence could possibly be due to ecologic factors, in that many other coccoliths within the assemblage are quite well preserved (Plate 7, Figs. 4-5; Plate 8, Figs. 1-2). This is not always the case, since some isolated shields are present (Plate 8, Fig. 3). The relatively good preservation of this shield, however, may mean that the adjoining shield could well have been lost before burial.
Sample 511-58-2, $108 \mathrm{~cm}$ from the black mudstone beneath the whitish limestone contains very few coccoliths, and these are generally not well preserved (Plate 8 , Figs. 4-6). Because of this it is difficult to get an idea of the diversity, but a reasonable variety of different forms is present. In addition to coccoliths, the sample contains calcite in the form of mollusk shell prisms which are probably from Inoceramus (Plate 8, Fig. 7). Clay minerals include fibrous forms which may be palygorskite (Plate 8, Fig. 8). In addition, pyrite framboids are not uncommon (Plate 8, Fig. 9).

\section{Conclusions from the Nannofloral Analysis}

Where coccoliths were present, either in the black mudstones or in the whitish limestones, the diversity of the assemblages was rather high, considering the generally adverse environment that prevailed in the basin. Opportunistic species were not present in any numbers beyond normal background levels. The main variant was in the absolute numbers of coccoliths. They were sparse in the black mudstones and plentiful in the limestones. In general, their numbers increased up-section so that they were more common in the Albian black mudstones than in the Aptian. Except where bioturbation had been extensive, coccoliths tended to be clustered in small pods which probably represented fecal pellets. This was particularly noticeable in the Aptian black mudstones, and may indicate that zooplankton were highly efficient in grazing the standing crop of calcareous nannoplankton, regardless of their numbers. The general increase in numbers of coccoliths in the $\mathrm{Al}$ bian toward the top of the black shale sequence may herald a relaxation of the conditions that were restricting circulation within the basin.

Preservation of coccoliths was surprisingly good among the black mudstones wherever nannofossils were found in open pores or cavities in the rock. Preservation of isolated specimens within the black shale matrix was not so good, although there was little evidence that wholesale dissolution of the carbonate had taken place. The presence of organic matter, therefore, did not greatly influence preservation, as has sometimes been suggested for coccoliths in these types of black shale. Specifically, there is little evidence that the breakdown of the organic matter to form $\mathrm{CO}_{2}$ caused significant dissolution of the assemblages. Perhaps the anoxic conditions were such that there was insufficient oxygen present to allow any appreciable combustion of the organic matter. Thus not enough $\mathrm{CO}_{2}$ would have been generated to cause significant dissolution of the assemblages. In any event, the buildup of $\mathrm{CO}_{2}$ cannot be cited as an explanation for the generally sparse occurrence of coccoliths in the black mudstones. Likewise, there is no evidence that the diversity of the assemblages was appreciably altered by dissolution.

Since both the condition of the nannofossils and the diversity of the assemblages indicate that little biogenic carbonate was lost through dissolution, the occurrence and abundance of coccoliths in the sequence of carbonate cycles cored at Site 511 must be a function of the 
productivity of the surface waters. Opportunistic species are few and the diversity of the assemblages does not change significantly between the black mudstones and the limestones; thus we are basically dealing with variations in productivity of normal marine nannofossil assemblages. The simplest explanation for these variations seems to be short-lived nutrient events resulting from upwelling or overturn in the expanding South Atlantic Basin. This explanation also implies that there was adequate surface water communication with normal marine floras elsewhere, to allow the Falkland nannoplankton assemblages to be stocked with floras of normal diversity where these nutrient events occurred. This is not to say that blooms of opportunistic species or of monospecific assemblages did not occur on occasions, as evidenced by the examples pointed out by Wise and Wind (1977) and Noël and Manivit (1978). Monospecific or species-restricted blooms, however, are not associated with the carbonate cycles we examined.

\section{DISCUSSION AND CONCLUSIONS}

Studies of nannofossil diversity and preservation suggest that selective dissolution or diagenesis cannot be the cause of interbedded Lower to mid-Cretaceous strata on the Falkland Plateau that are relatively rich and poor, respectively, in calcareous nannofossils. Preservation is best in intervals characterized by low carbonate and relatively high organic carbon contents. Stable isotope measurements of carbonate (primarily calcareous nannofossils) do not adequately constrain the origin of the cyclicity of carbonate and organic carbon contents, although the $\delta^{13} \mathrm{C}$ values suggest that diagenetic recrystallization is not overextensive in the samples studied, even though carbonate contents are relatively low. The $\delta^{13} \mathrm{C}$ data might suggest that more nannofossil-rich intervals are due to higher nutrient supply and overturn of deeper waters at the site, because samples with progressively higher carbonate contents above $10 \%$ have lighter $\delta^{13} \mathrm{C}$ values. The overturn of surface and deeper waters could have oxygenated bottom waters at the site, leading to oxidation of organic carbon and overall lower organic carbon values in the lighter-colored, bioturbated, relatively more carbonate rich intervals. This interpretation seems reasonable to us and does not violate the constraints of available data. A corollary of this interpretation is that periods of lower productivity were due to a more stably stratified water column, development of low oxygen conditions in intermediate water masses, and consequent increased preservation of the little organic matter that was produced in surface waters. Overall, the degree of oxygenation was higher in the early Albian at Site 511 than at earlier times and organic carbon preservation was poorer.

One further possibility should be considered in any attempt to explain the interbedding of relatively carbonate-rich and organic-carbon-poor intervals. The irregular pattern of interbedding might indicate dilution of carbonate supply by terrigenous clastic material redeposited downslope from one or more local topographic highs. Some of the strata in Unit 6 exhibit sedimentary structures such as sharp contacts and irregular lamina- tion, which, although cryptic, may suggest a turbiditic origin for at least some of the organic-carbon-rich mud. Similar arguments have been made, for example, for organic-carbon-rich Cretaceous sequences at Site 530 in the South Atlantic (Dean et al., in press) and several sites in the North Atlantic (de Graciansky et al., 1979). The redeposition of sediment could periodically have diluted carbonate produced in surface waters above the site, thereby leading to the cyclic or interbedded chalky layers and dark mudstones in the upper part of Unit 6. Such redeposited sediment probably could not have been derived from the continent, since the adjacent South American shoreline was at least 100 to $150 \mathrm{~km}$ away. Sources would have to have been more local, perhaps on the flanks of subaerially exposed basement pinnacles in the region of the site. There is, however, no direct evidence for the existence of such features during the Aptian-Albian and, unfortunately, data on the regional tectonic framework are inadequate for proper evaluation of the probability that such features may have existed. Since the black mudstones are the overwhelmingly dominant lithology, a source for any reworked sediment would have to have been quite extensive. In any event, the main differences between the pre-lower Albian black shales and the lower Albian black shales must still have been related to a change in paleoenvironment, specifically the degree of oxygenation of intermediate and bottom waters.

\section{ACKNOWLEDGMENTS}

We thank Murlene Clark and Robert Cunningham (Exxon Production Research Co., Houston) for their critical review of the manuscript, which was typed by Pamela Rhymes. The coccolith studies were carried out at Florida State University and were supported by NSF grant DPP 80-2082. We thank William I. Miller, III, for operation of the SEM. The geochemical analyses were carried out in laboratories at the University of South Carolina, the United States Geological Survey, Denver, and the Global Chemical Corporation.

\section{REFERENCES}

Arthur, M. A., 1979. North Atlantic Cretaceous black shales: The record at Site 398 and a brief comparison with other occurrences. In Sibuet, J.-C., Ryan, W. B. F., et al., Init. Repts. DSDP, 47, Pt. 2: Washington (U.S. Govt. Printing Office), 719-751.

Arthur, M. A., Dean, W. E., and Stow, D. A. V., in press. The importance of downslope movement in the deposition of fine-grained organic-carbon-rich sediment in the deep sea. In Stow, D. A. V, and Piper, D. J. W. (Eds.), Fine-grained Sediments, Deep-water Processes and Environments: London (Geol. Soc. Lond., Spec. Publ),

Arthur, M. A., and Natland, J. H., 1979. Carbonaceous sediments in the North and South Atlantic: The role of salinity in stable stratification of Early Cretaceous basins. In Talwani, M., Hay, W. W., and Ryan, W. B. F. (Eds.), Deep Drilling Results in the Atlantic Ocean: Continental Margins and Paleoenvironment. Am. Geophys. Union, Maurice Ewing Ser., 3:375-401.

Barker, P., Dalziel, I. W. D., et al., 1977. Init. Repts. DSDP, 36: Washington (U.S. Govt. Printing Office).

Craig, H., 1957. Isotopic standards for carbon and oxygen and correction factors for mass spectrometric analysis of carbon dioxide. Geochim. Cosmochim. Acta., 12:133-149.

1965. The measurement of oxygen isotope paleotemperatures. Stable Isotopes in Oceanographic Studies and Paleotemperatures: Spoleto (Consiglio Nazionale delle Ricerche), pp. 1-24.

Dean, W. E., Arthur, M. A., and Stow, D. A. V., in press. Origin and geochemistry of Cretaceous deep-sea black shales and multicolored claystones, with emphasis on Deep Sea Drilling Project Site 530, Southern Angola Basin. In Hay, W. W., Sibuet, J.-C., et 
al., Init. Repts. DSDP, 75: Washington (U.S. Govt. Printing Office).

Dean, W. E., Gardner, J. V., Jansa, L. F., Čepek, P., and Seibold, E., 1978. Cyclic sedimentation along the continental margin of Northwest Africa, DSDP Leg 41. In Lancelot, Y., Seibold, E., et al., Init. Repts. DSDP, 41: Washington (U.S. Govt. Printing Office), 965-989.

de Graciansky, P. C., Auffret, G. A., Dupeuble, P., Montadert, L., and Müller, C., 1979. Interpretation of depositional environments of the Aptian/Albian black shales on the north margin of the Bay of Biscay (DSDP Sites 400 and 402). In Montadert, L., Roberts, D. G., et al., Init. Repts. DSDP, 48: Washington (U.S. Govt. Printing Office), 877-908.

de Graciansky, P. C., and Chenet, P. V., 1979. Sedimentological study of Cores 138 to 56 (upper Hauterivian to middle Cenomanian): An attempt at reconstruction of paleoenvironments. In Sibuet, J.-C., Ryan, W. B. F., et al., Init. Repts. DSDP, 47, Pt. 2: Washington (U.S. Govt. Printing Office), 403-418.

DeMaster, D. J., 1981. The supply and accumulation of silica in the marine environment. Geochim. Cosmochim. Acta, 45:1715-1732.

Diester-Haass, L., and Schrader, H. J., 1979. Neogene coastal upwelling history off Northwest and Southwest Africa. Mar. Geol., 29: 39-53.

Glenn, C. R., and Arthur, M. A., 1982. Deposition of black shales and the cycling of oceanic phosphate. Geol. Soc. Am. Abstract with Programs, 14:497. (Abstract)

Habib, D., 1979. Sedimentary origin of North Atlantic Cretaceous palynofacies. In Talwani, M., Hay, W. W., and Ryan, W. B. F. (Eds.), Deep Drilling Results in the Atlantic Ocean: Continental Margins and Paleoenvironment. Am. Geophys. Union, Maurice Ewing Ser., 3:420-437.

Hattin, D. E., 1975. Petrology and origin of fecal pellets in Upper Cretaceous strata of Kansas and Saskatchewan. J. Sed. Petrol., 45:686-696.

Heath, G. R., 1974. Dissolved silica and deep-sea sediments. In Hay, W. W. (Ed.), Studies in Paleoceanography. Soc. Econ. Paleontol. Mineral., Spec. Publ., 20:77-93.

Honjo, S., 1976. Coccoliths: Production, transportation, and sedimentation. Mar. Micropaleontol., 1:65-79.

Hudson, J. D., 1977. Stable isotopes and limestone lithification. J. Geol. Soc. London, 133:637-660.
McCave, I. N., 1979. Depositional features of organic-carbon-rich black and green mudstones at DSDP Sites 386 and 387, western North Atlantic. In Tucholke, B. E., Vogt, P. R., et al., Init. Repts. DSDP, 43: Washington (U.S. Govt. Printing Office), 411-416.

Müller, P. J., and Suess, E., 1979. Productivity, sedimentation rate, and sedimentary organic matter in the oceans-organic preservation. Deep Sea Res., 26A:1347-1362.

Natland, J. H., 1978. Composition, provenance, and diagenesis of Cretaceous clastic sediments drilled on the Atlantic continental rise off southern Africa, DSDP Site 361-implications for the early circulation of the South Atlantic. In Bolli, H. M., Ryan, W. B. F., et al., Init. Repts. DSDP, 40: Washington (U.S. Govt. Printing Office), 1025-1061.

Noël, D., and Manivit, H., 1978. Nannofaciès de "black shales" aptiennes et albiennes d'Atlantique sud (Legs 36 to 40): Intérèt sedimentologique. Bull. Soc. Geol. France (7), 20(no.4):491-502.

Roth, P. H., Mullin, M. M., and Berger, W. H., 1975. Coccolith sedimentation by fecal pellets: Laboratory experiments and field observations. Geol. Soc. Am. Bull., 86:1079-1084.

Scholle, P. A., and Arthur, M. A., 1980. Carbon isotopic fluctuations in pelagic limestones: Potential stratigraphic and petroleum exploration tool. Am. Assoc. Pet. Geol. Bull., 64:67-87.

Sliter, W. V., 1977. Cretaceous foraminifers from the southwestern Atlantic Ocean, Leg 36, Deep Sea Drilling Project. In Barker, P. F., Dalziel, I. W. D., et al., Init. Repts. DSDP, 36: Washington (U.S. Govt. Printing Office), 519-573.

Suess, E., 1980. Particulate organic carbon flux to the ocean-surface productivity and oxygen utilization. Nature, 288:260-263.

Thiede, J., and van Andel, Tj. H., 1977. The paleoenvironment of anaerobic sediments in the late Mesozoic South Atlantic Ocean. Earth Planet. Sci. Lett., 33:301-309.

Tucholke, B. E., and Vogt, P. R., 1979. Western North Atlantic: Sedimentary evolution and aspects of tectonic history. In Tucholke, B. E., Vogt, P. R., et al., Init. Repts. DSDP, 43: Washington (U.S. Govt. Printing Office), 791-825.

Wise, S. W. Jr., and Wind, F. H., 1977. Mesozoic and Cenozoic calcareous nannofossils recovered by DSDP Leg 36 drilling on the Falkland Plateau, southwest Atlantic sector of the Southern Ocean. In Barker, P. F., Dalziel, I. W. D., et al., Init. Repts. DSDP, 36: Washington (U.S. Govt. Printing Office), 269-491. 

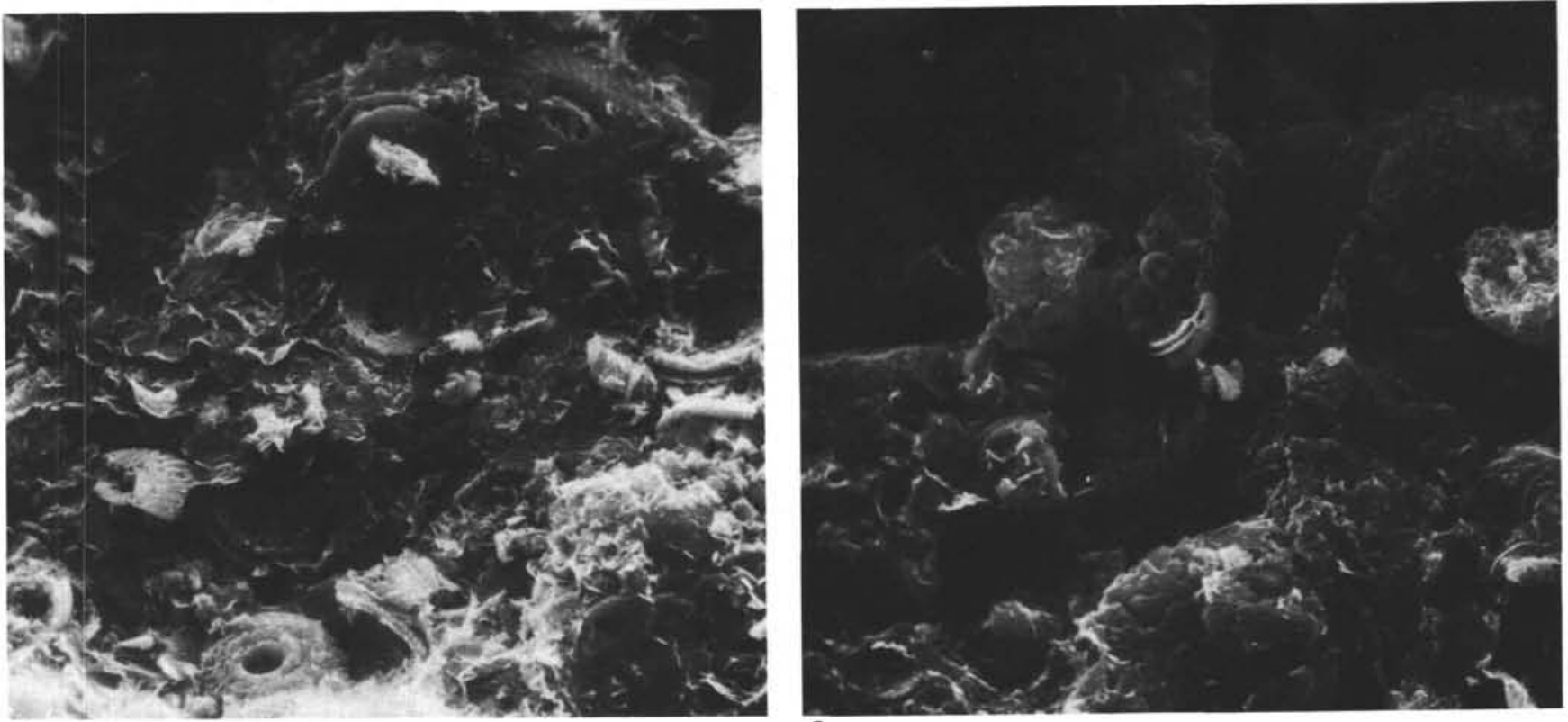

$$
1
$$

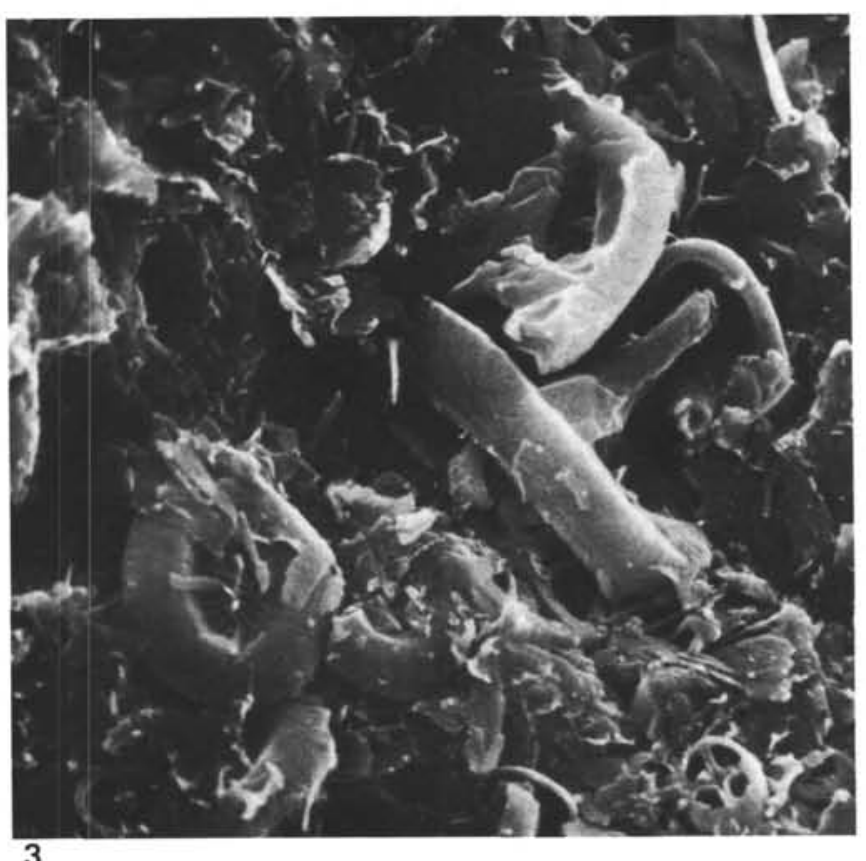

2

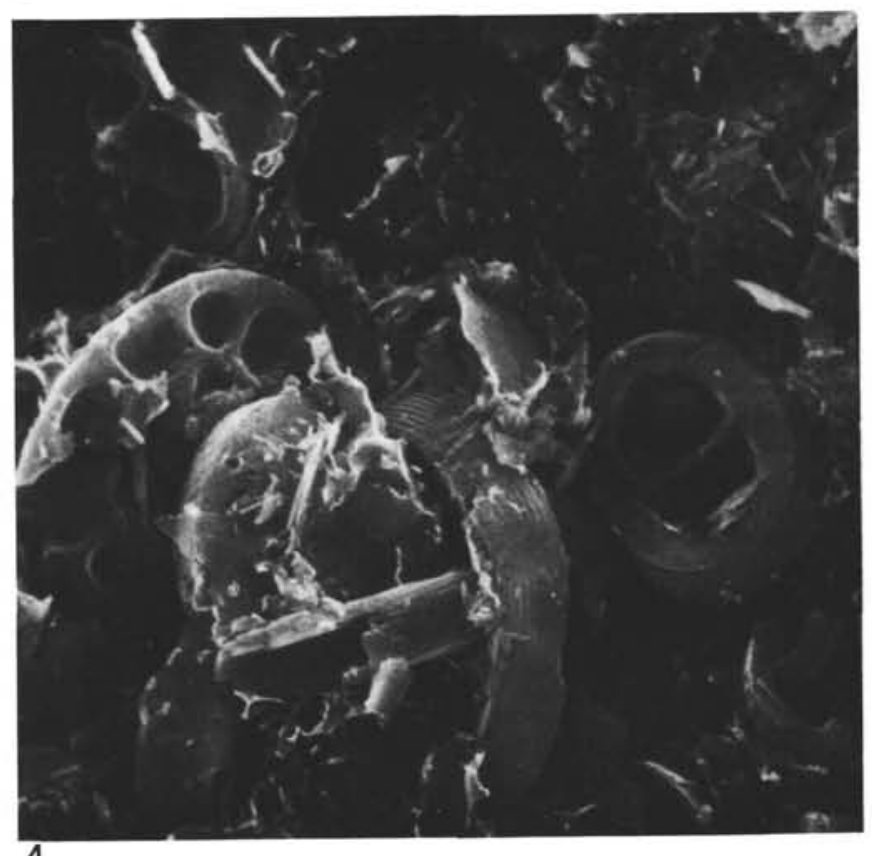

4

Plate 1. Albian black mudstone, Sample 511-57-6, $4 \mathrm{~cm}$. 1. Characteristic black mudstone matrix with scattered coccoliths, mostly Watznaueria; $\times 3000$. 2. Angular cavities in the mudstone matrix, possibly from the dissolution of lath-shaped mineral (silicate?) grains; $\times 1400$. 3-4. Crude clusters of well-preserved coccoliths, (3) Repagulum parvidentatum, left center, $\times 7000$, (4) Rhagodiscus asper, left center, $\times 6500$. 


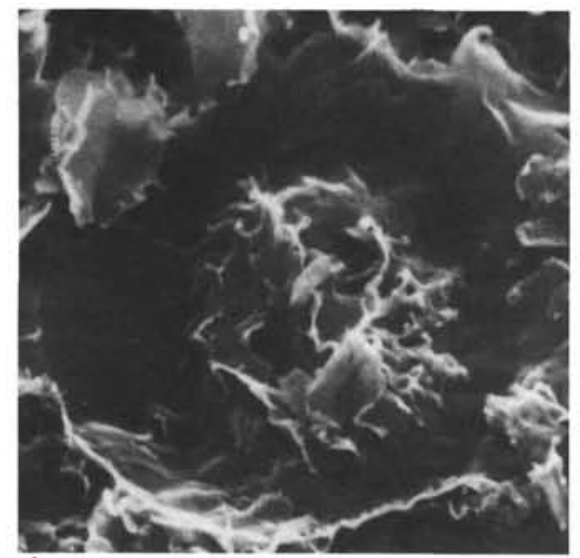

1

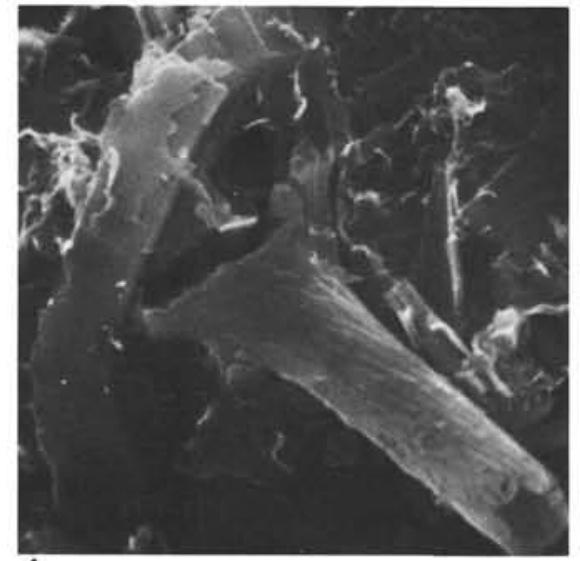

4

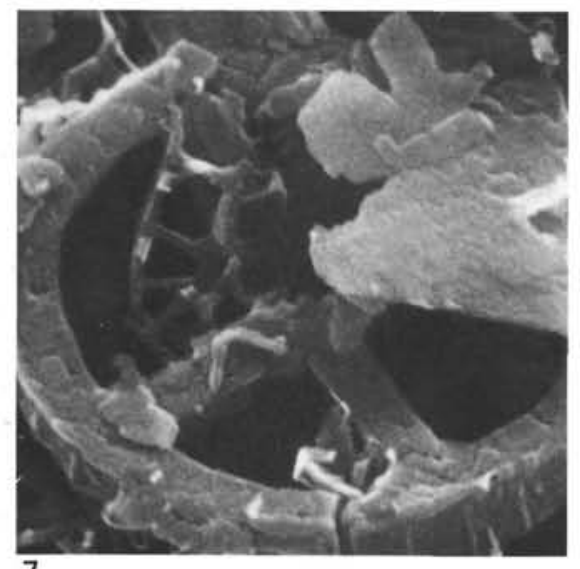

7

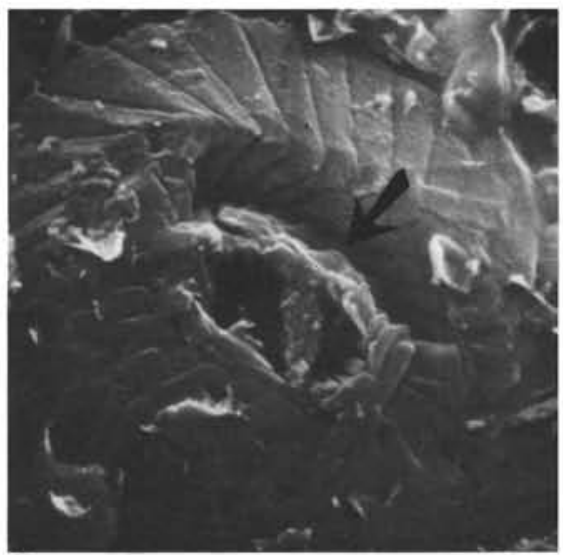

2

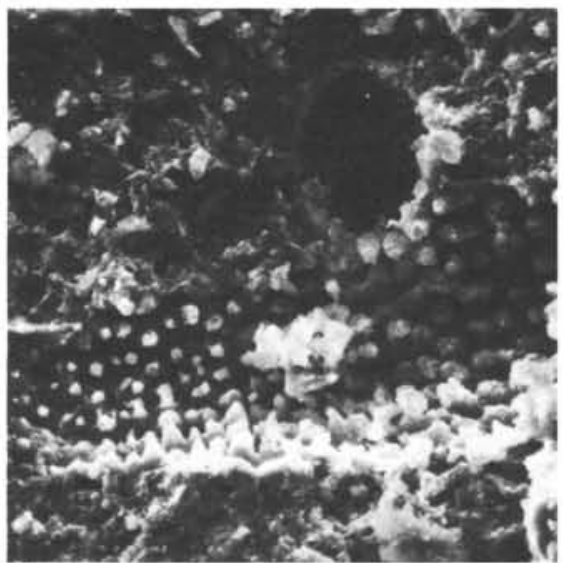

5

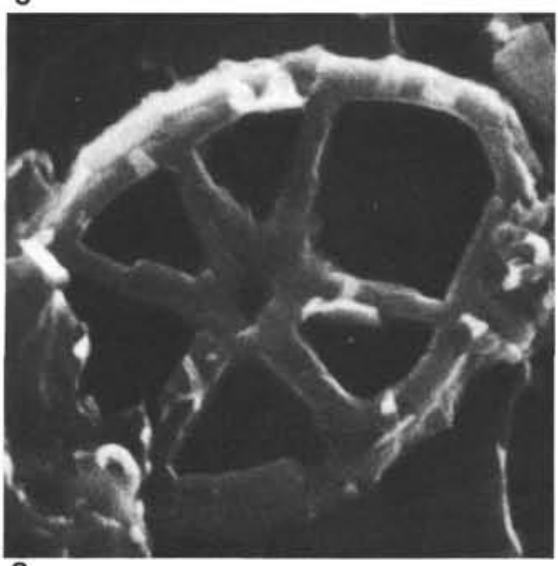

8
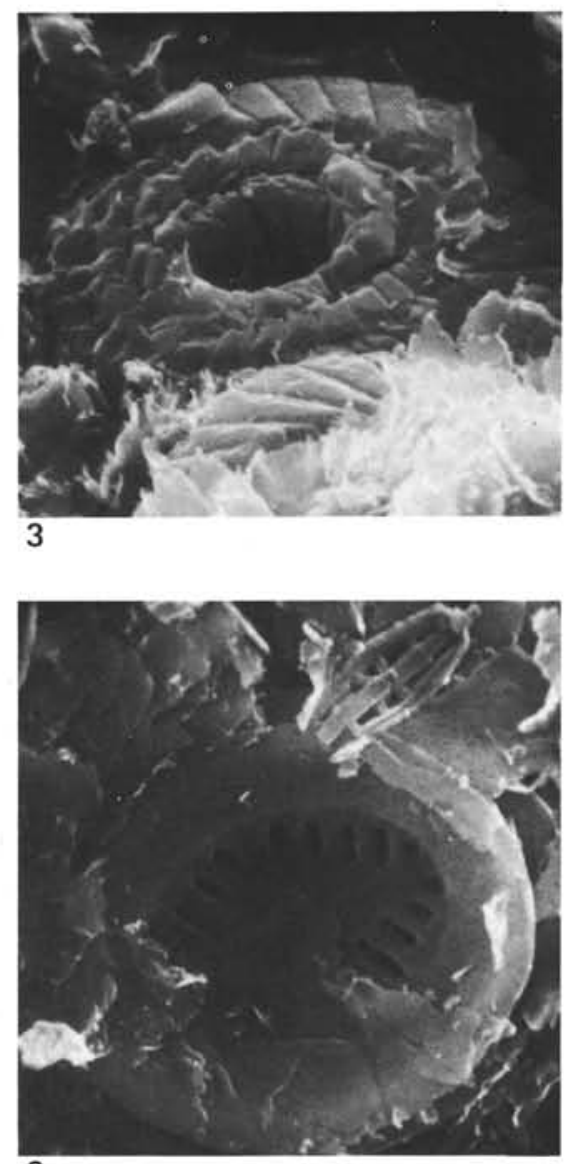

6

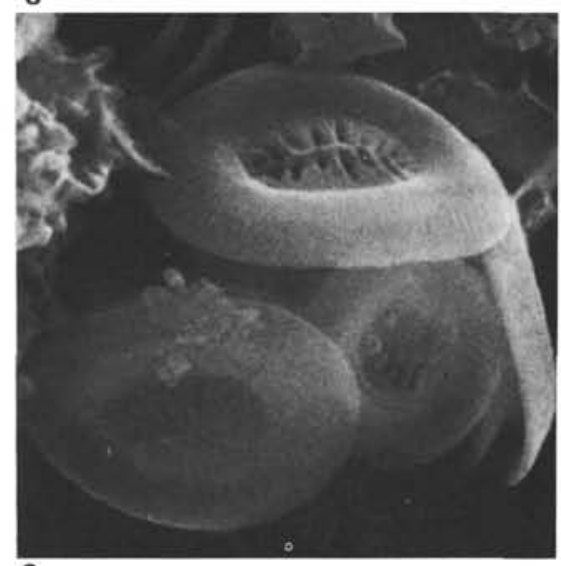

Plate 2. Albian black mudstone, Sample 511-57-6, $4 \mathrm{~cm}$. Micrographs showing characteristic states of preservation of coccoliths (except for Fig. 5) within the mudstone. 1. Impression of a coccolith left when the sample was fractured; this is probably not a dissolution mold; $\times 11,000$. 2 . Watznaueria sp., inner cycle of elements along the top side of the distal shield removed by mechanical fracturing of sample, $\times 11,000$. 3. Watznaueria sp., $\times 9500$. 4. Axopodorhabdus dietzmanni, stem broken by mechanical fracture, $\times 8500$. 5. Impression of a dissolved radiolarian test; $\times 240 ; 6$. Polypodorhabdus madingleyensis (large specimen), Corollithion pauciramosus (small specimen), $\times 9500$. 7. Corollithion achylosum, $\times 18,000$. 8. Corollithion geometricum, $\times 29,000$. 9. Coccosphere of Repagulum parvidentatum, $\times 10,000$. 

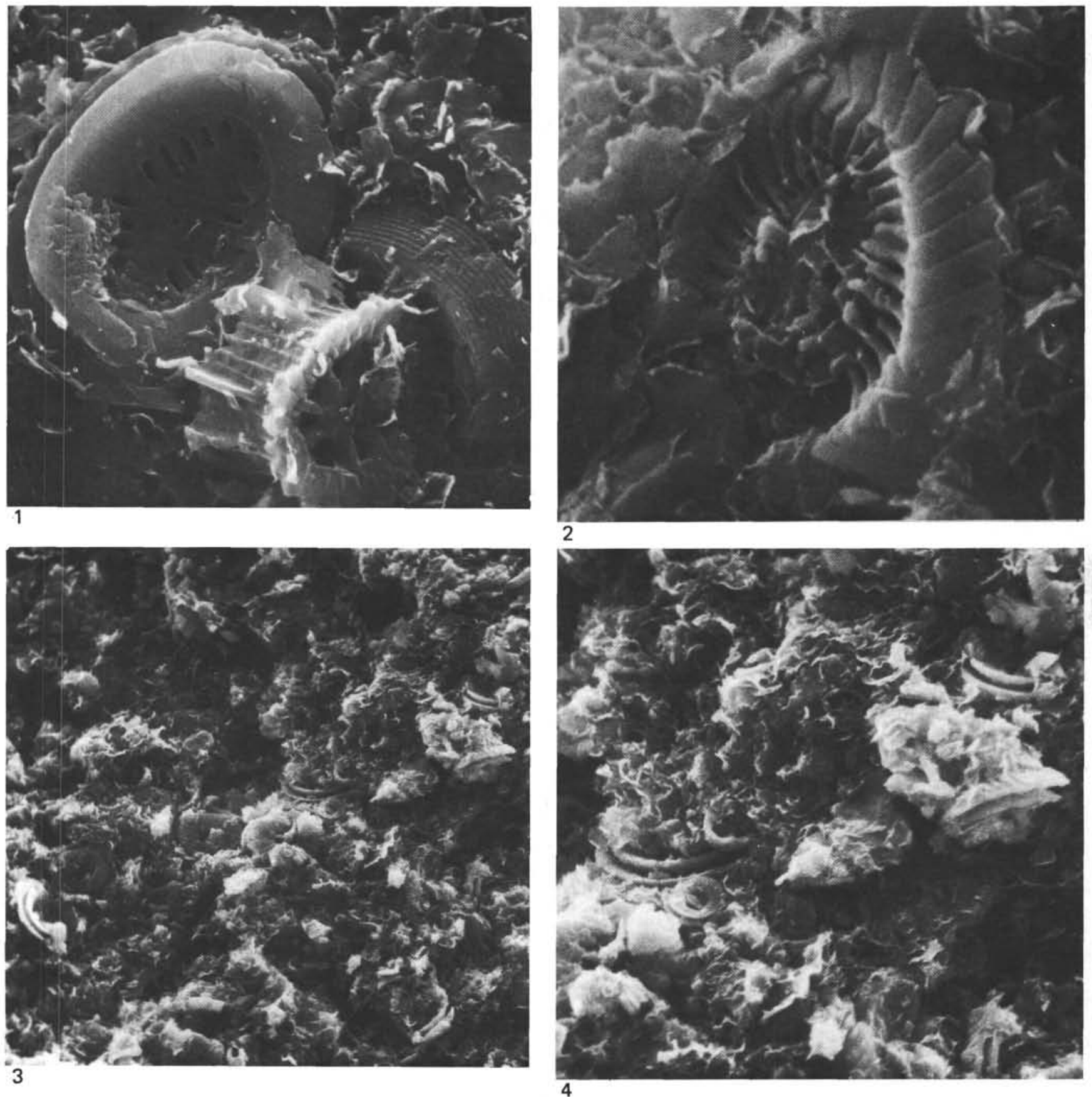

Plate 3. Albian. 1-2. Black mudstone Sample 511-57-6, $4 \mathrm{~cm}$, (1) well-preserved Polypodorhabdus madingleyensis (left) and Stephanolithion laffittei (lower center), $\times 9500$, (2) Watznaueria sp. (center etched), $\times 17,000$. 3-4. White limestone Sample 511-57-6, 15 cm, showing even distribution of coccoliths within a highly bioturbated matrix, (3) $\times 1700,(4) \times 3400$. 

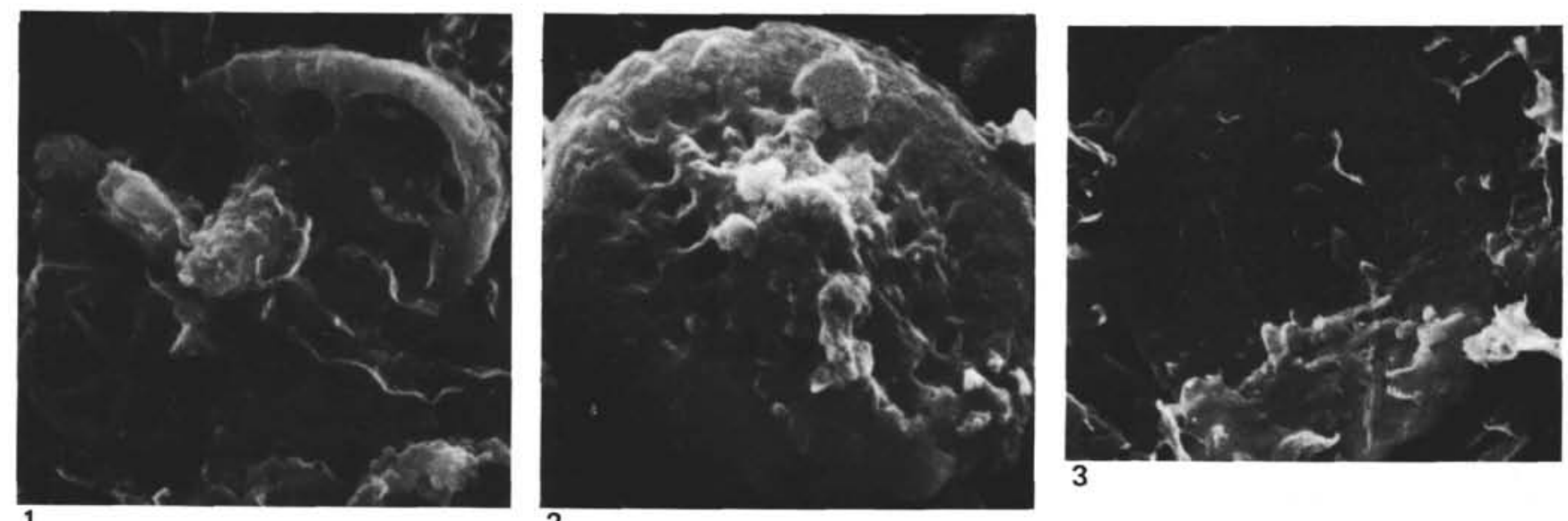

1

2

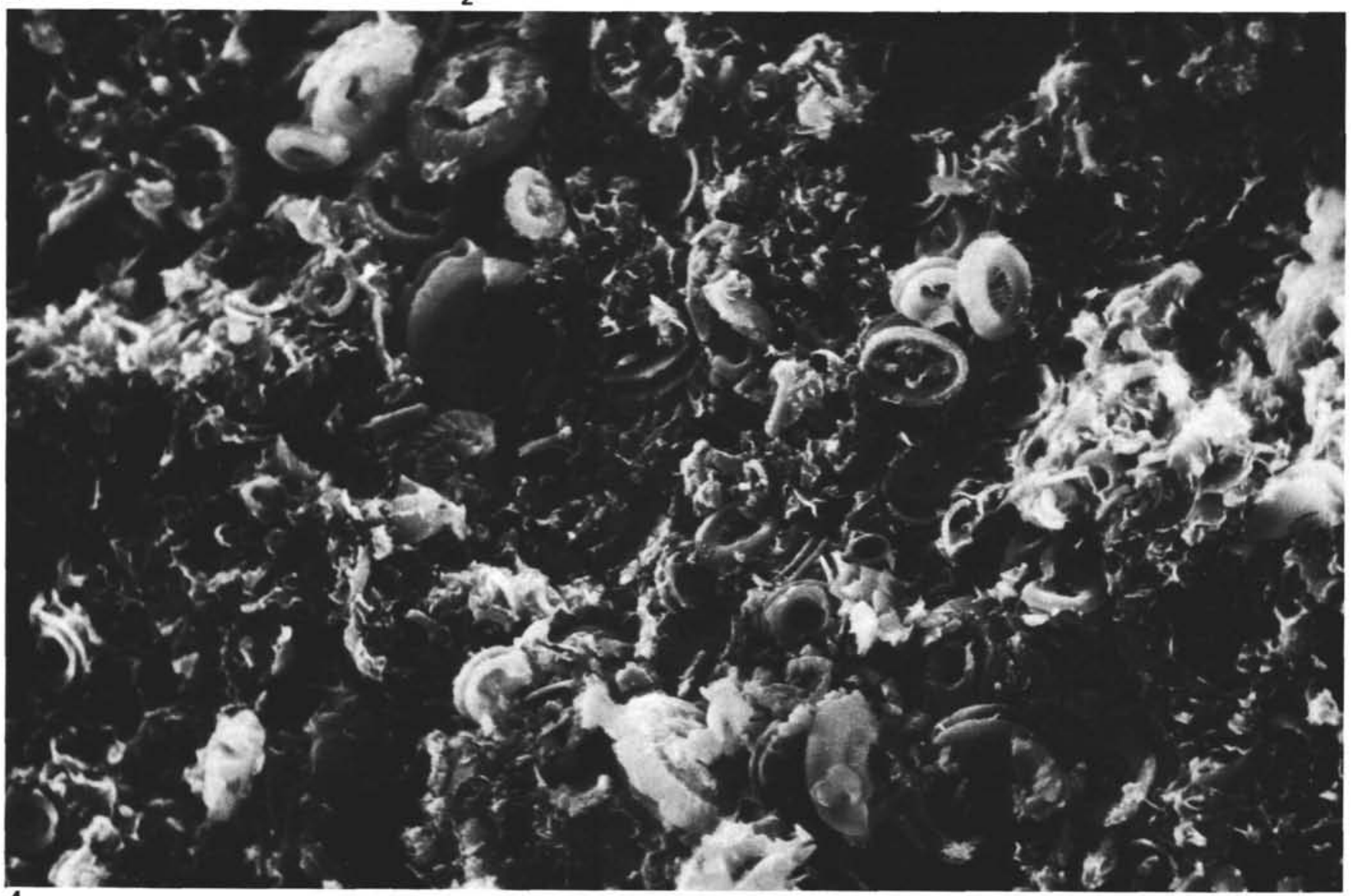

Plate 4. Albian. 1-3. Characteristic states of preservation within the highly bioturbated white limestone of the Albian carbonate cycle, Sample $511-57-6,15 \mathrm{~cm}$. Diagenesis has obscured the surface features of the coccoliths, (1) Corollithion geometricum (lower left), Rhagodiscus? sp. (center), $\times 10,000$, (2) Cretarhabdus conicus, $\times 9000$, (3) gen. et spec. indet., $\times 9000$. 4. Black mudstone Sample $511-57-6,41 \mathrm{~cm}$, below the carbonate bed, showing a large cluster or pod of coccoliths; such pods stand out clearly from the matrix of the rock, which contains few coccoliths; $\times 3500$. 


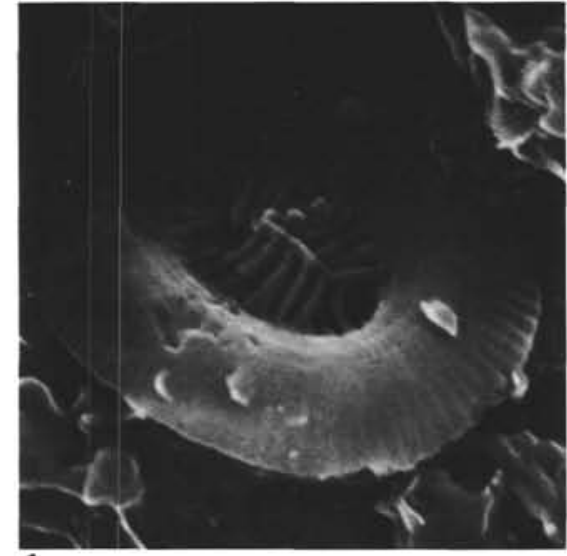

1

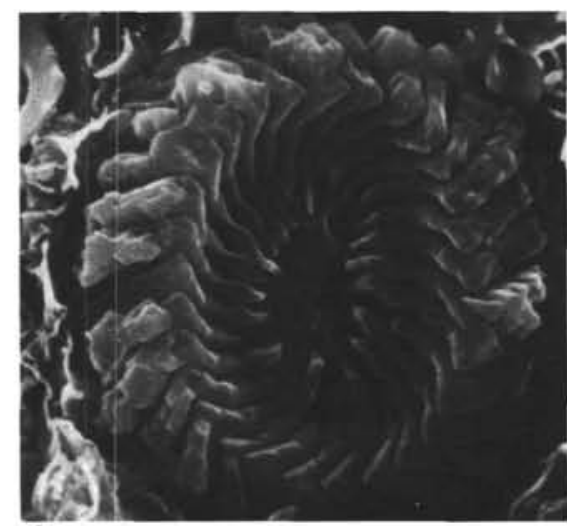

4

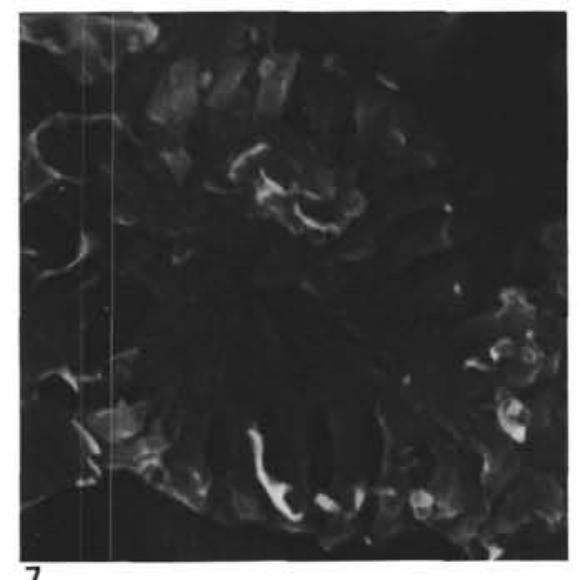

7

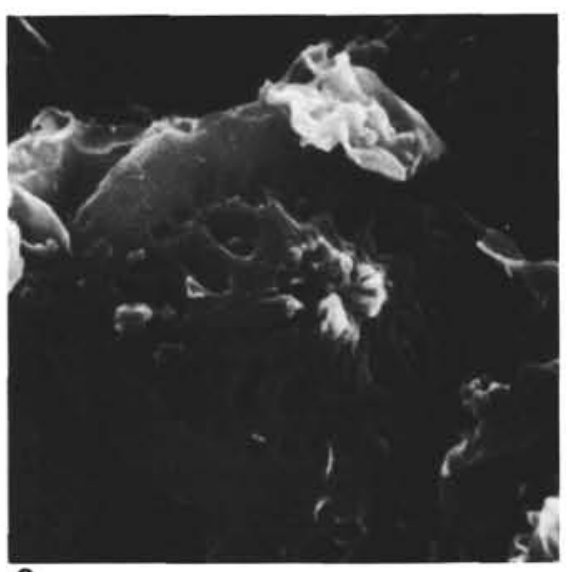

2

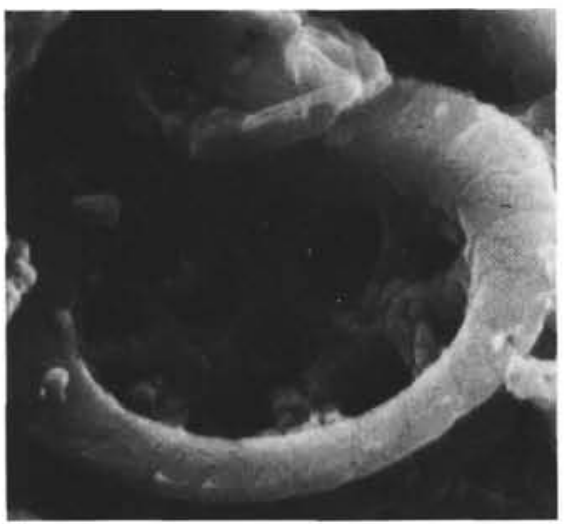

5

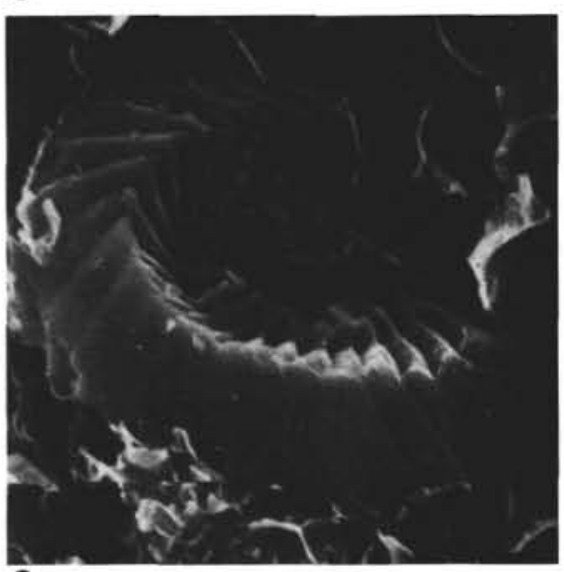

8

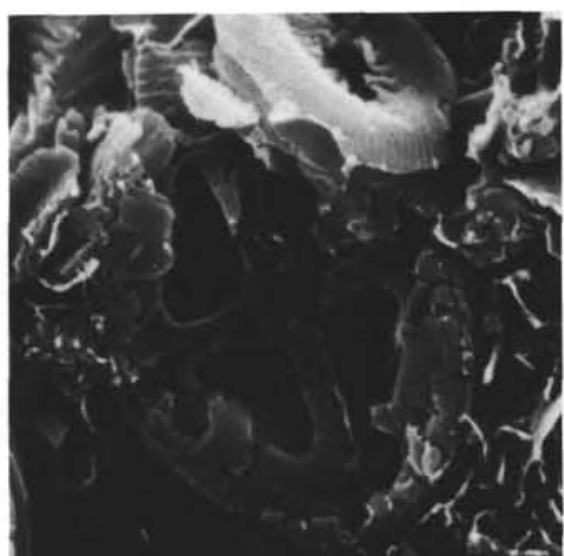

3

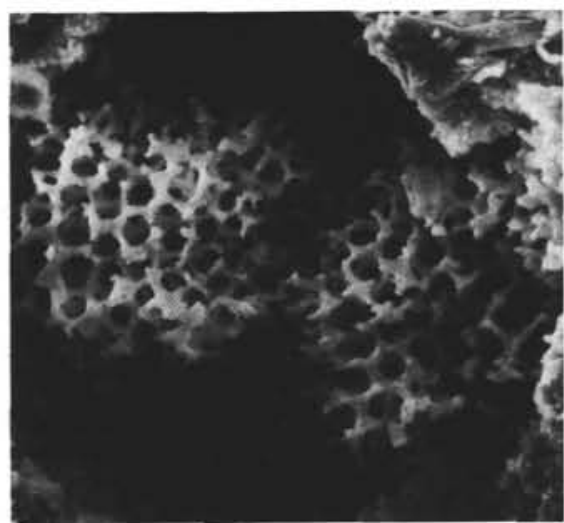

6

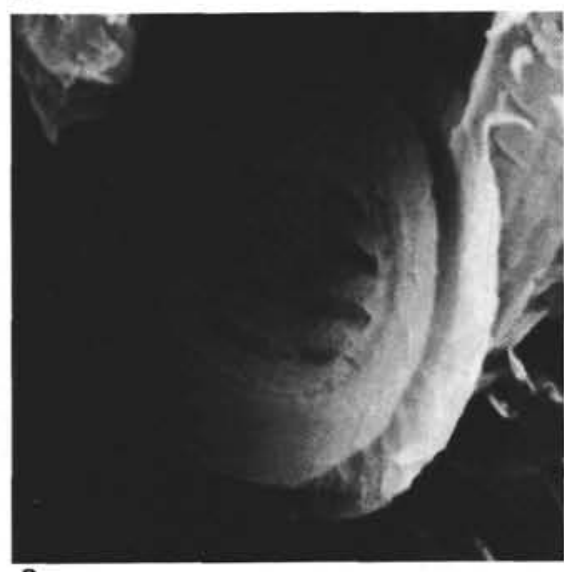

9

Plate 5. 1-6. Albian black mudstone Sample 511-57-6, $41 \mathrm{~cm}$; variable state of preservation of coccoliths (except for Fig. 6) within the mudstone, (1) Repagulum parvidentatum, $\times 14,000$, (2) Cretarhabdus surirellus, $\times 9000$, (3) gen. et spec. indet., $\times 9500$, (4) Watznaueria sp., heavily dissolved, $\times 9000,(5)$ Retacapsa angustiforata, $\times 17,000,(6)$ partially dissolved radiolarian test, $\times 630$. 7-9. Aptian black mudstone Sample 511$58-2,77 \mathrm{~cm}$, showing poor coccolith preservation within the matrix (Figs. 7-8) and good preservation within cavities in the matrix, (7) Polypodorhabdus madingleyensis, heavily dissolved, $\times 14,500,(8)$ Watznaueria sp., partially dissolved, $\times 10,000$, (9) Sollasites horticus, well preserved, $\times 15,000$. 

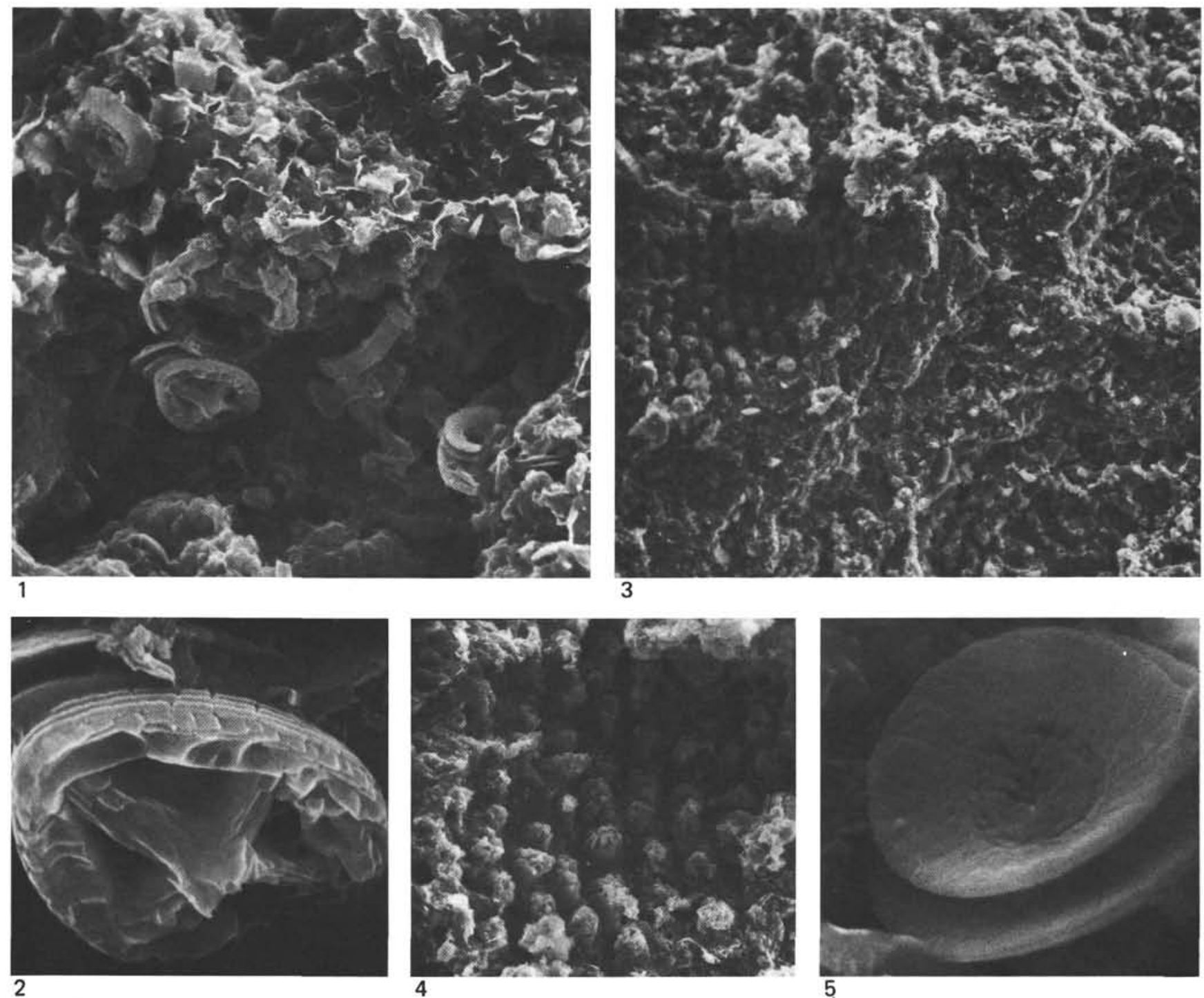
2

Plate 6. Aptian black mudstone, Sample $511-58-2,77 \mathrm{~cm}$. 1. Cavity within the black mudstone containing some well-preserved coccoliths; $\times 3100$. 2. Detail of Figure 1, Acaenolithus sp., $\times 10,000$. 3. Impression of a dissolved radiolarian test within the mudstone matrix, $\times 300$. 4. Detail of Figure 3, showing a mold of a radiolarian test, $\times 570$. 5. Detail of Figure 4 (top center), showing a well-preserved coccolith, Watznaueria barnesae, $\times 12,500$. 

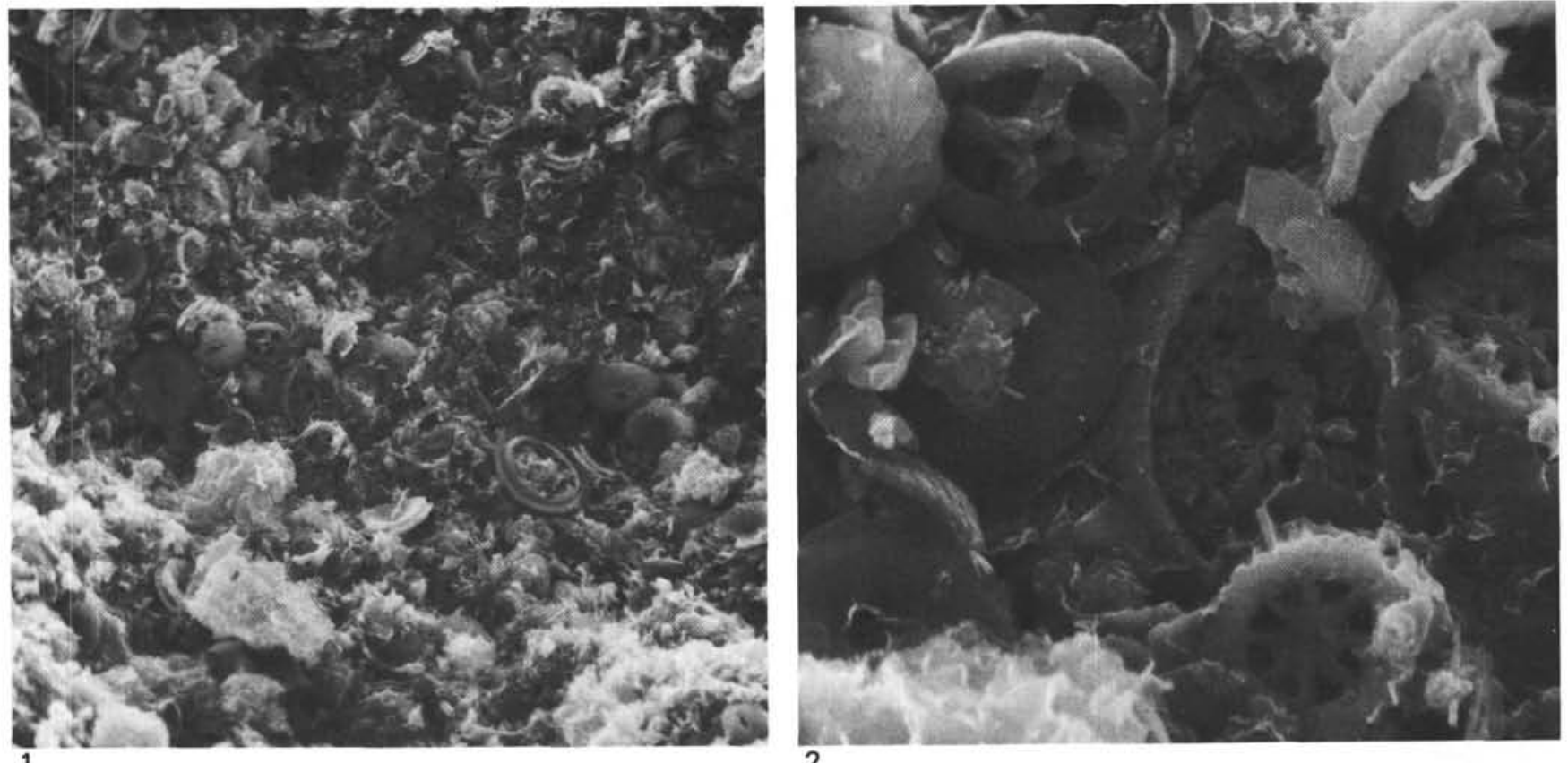

2
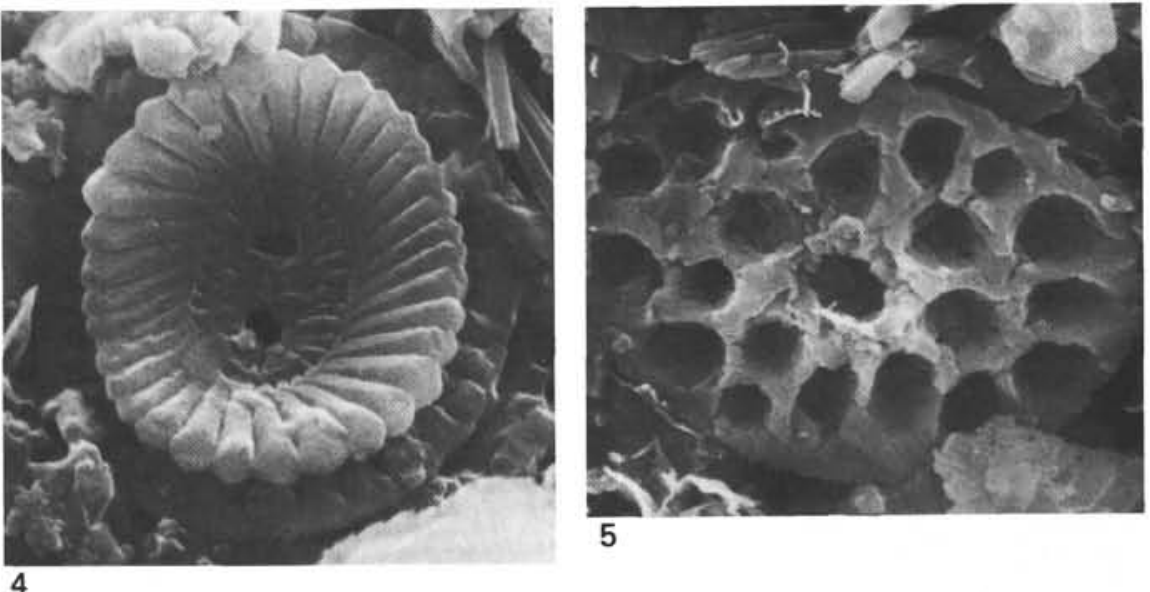

4
3

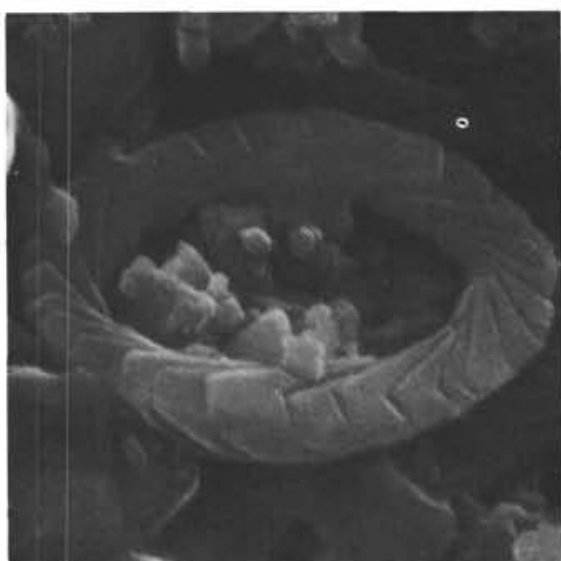

Plate 7. Aptian white limestone, Sample 511-58-2, $99 \mathrm{~cm}$. 1-2. Large clusters or pods of coccoliths which are believed to represent fecal pellets; (1) $\times 1500$, (2) detail of Figure 1, center; Stephanolithion laffittei (right, lower and center), Vekshinella stradneri (upper left), Watznaueria sp. (forms on left, top, center, and bottom), $\times 7000$. 3-5. High diversity and good preservation of coccoliths, (3) Zygodiscus sp., $\times 21,000,(4)$ Watznaueria biporta, $\times 9000,(5)$ Rhagodiscus asper, $\times 8000$. 

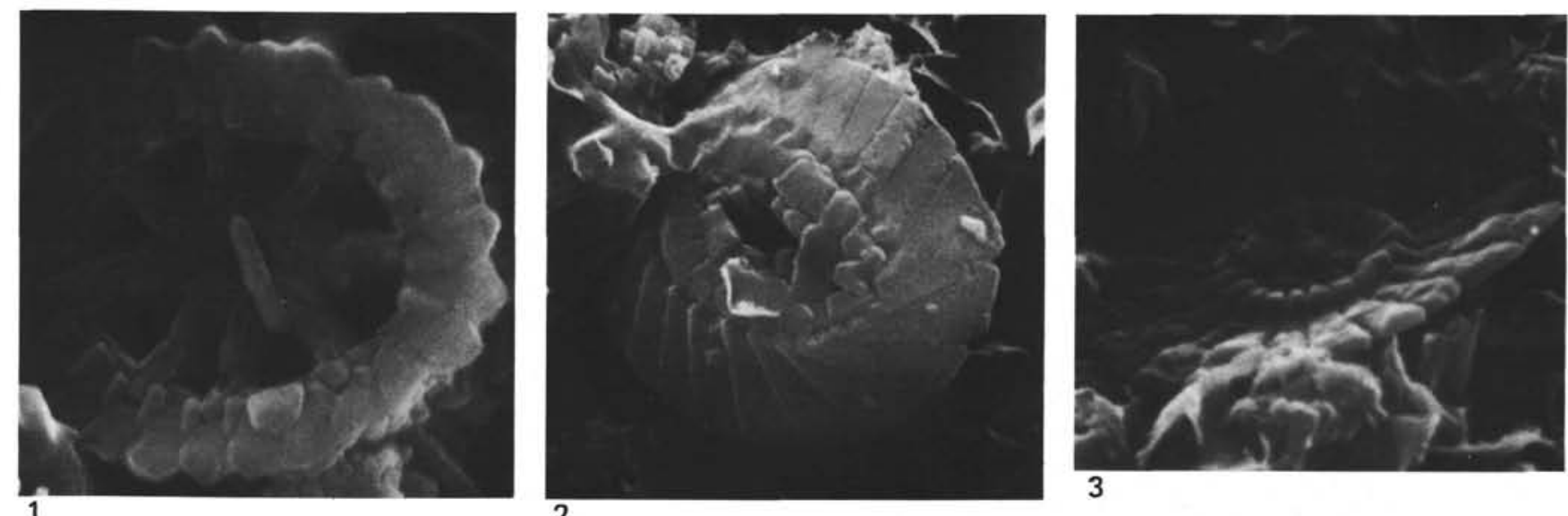

\section{3}

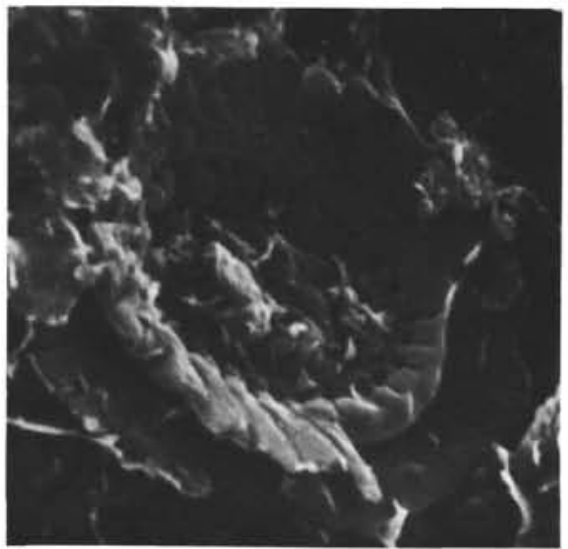

4

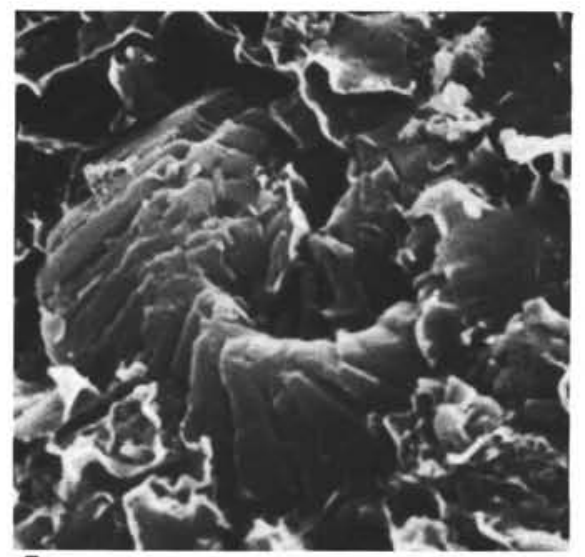

5

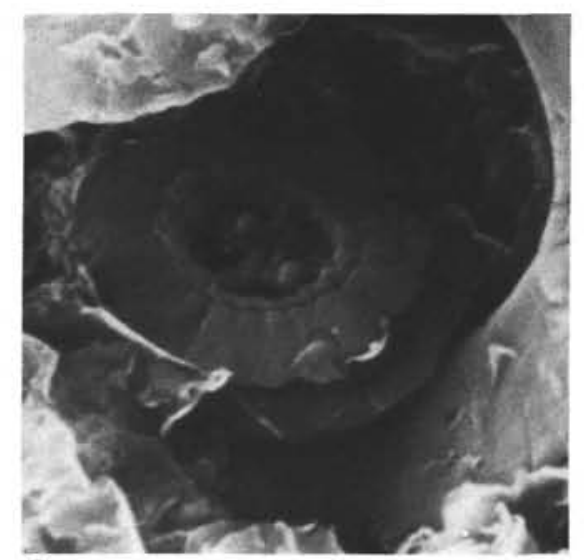

6
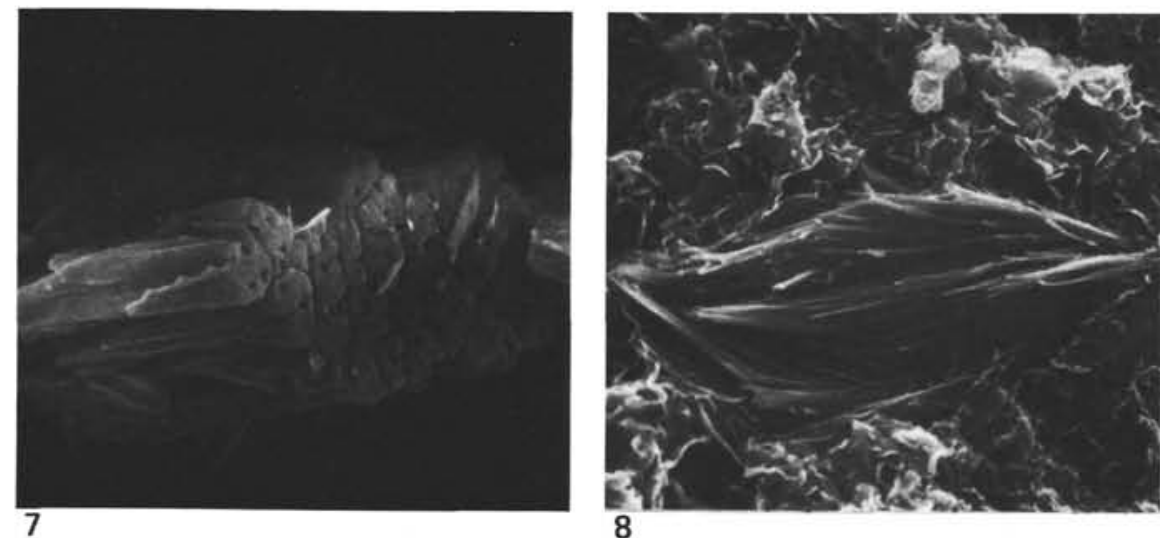

8

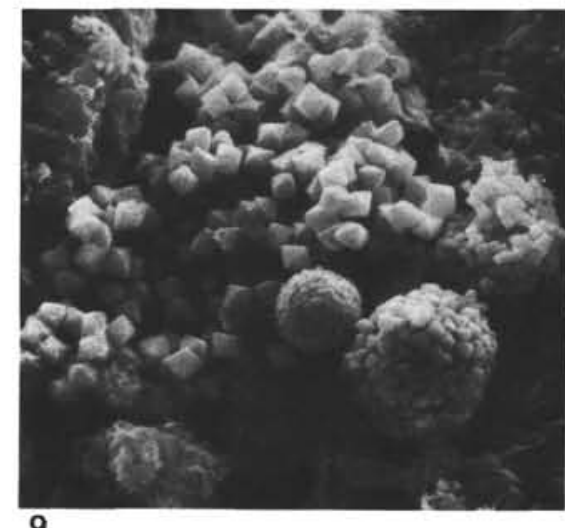

9

Plate 8. Aptian. 1-3. Relatively good preservation and diversity of coccoliths in the whitish limestone of the Aptian carbonate cycle, Sample 51158-2, $99 \mathrm{~cm}$, (1) Stephanolithion laffittei, $\times 19,500$, (2) Watznaueria sp., $\times 12,000$, (3) Biscutum sp., isolated distal shield, $\times 16,000$. 4-6. Rather poorly preserved coccoliths of Aptian black mudstone Sample 511-58-2, $108 \mathrm{~cm}$, subjacent to the white limestone shown above, (4) Watznaueria sp. $\times 11,000,(5)$ Watznaueria sp., $\times 10,500$; (6) Palaeopontosphaera sp., $\times 12,000$. 7-9. Other components of the black mudstone, (7) mollusk shell prisms, probably from Inoceramus, $\times 4500$, (8) a fibrous clay mineral, possibly palygorskite, $\times 4100$, (9) pyrite framboids and loose aggregates of octahedral crystals, $\times 2300$. 